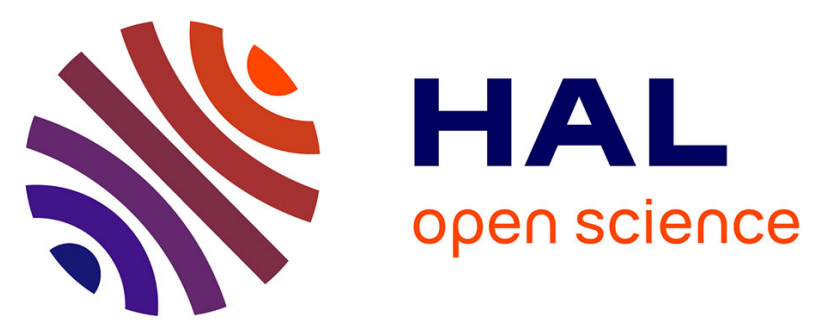

\title{
Exhumation of the ultra high-pressure Tso Morari unit in eastern Ladakh (NW Himalaya): a case study.
} Julia de Sigoyer, Stéphane Guillot, Pierre Dick

\section{To cite this version:}

Julia de Sigoyer, Stéphane Guillot, Pierre Dick. Exhumation of the ultra high-pressure Tso Morari unit in eastern Ladakh (NW Himalaya): a case study.. Tectonics, 2004, 23(3), pp.TC3003. 10.1029/2002TC001492. hal-00103128

\section{HAL Id: hal-00103128 \\ https://hal.science/hal-00103128}

Submitted on 5 Oct 2006

HAL is a multi-disciplinary open access archive for the deposit and dissemination of scientific research documents, whether they are published or not. The documents may come from teaching and research institutions in France or abroad, or from public or private research centers.
L'archive ouverte pluridisciplinaire HAL, est destinée au dépôt et à la diffusion de documents scientifiques de niveau recherche, publiés ou non, émanant des établissements d'enseignement et de recherche français ou étrangers, des laboratoires publics ou privés. 


\title{
Exhumation of the ultra high-pressure Tso Morari unit in eastern Ladakh (NW \\ Himalaya): a case study
}

\author{
Julia de Sigoyer ${ }^{1}$, Stéphane Guillot ${ }^{2}$ and Pierre Dick ${ }^{3}$.
}

Laboratoire de Géologie, CNRS-UMR 8538, Ecole Normale Supérieure de Paris, 24 rue Lhomond, 75231 Paris cedex 05, France. Tel: 00-33-1-44-32-22-75

2

Laboratoire de Sciences de la Terre, CNRS-UMR 5570, Université Lyon I et Ecole Normale Supérieure de Lyon - 2 rue Dubois, Bâtiment Géode, 69622 Villeurbanne cedex, France. 3

Institut de géologie, 11 E. Argand, Université de Neuchâtel, 2007 Neuchâtel, Suisse.

Abstract. Exhumation processes of the ultra-high pressure (UHP) Tso Morari dome (NWHimalaya) are investigated using structural, petrological and geochronological data. The UHP Tso Morari unit is bounded by the low-grade metamorphic Indus Suture Zone to the NE and Mata unit to the SW. Three deformation phases (D1, D2 and D3) are observed. Only D3 is common to the UHP unit and the surrounding units. In the UHP unit, the first deformation phase (D1) produced upright folds, under eclogitic conditions (> $20 \mathrm{kbar}$; $580 \pm 60{ }^{\circ} \mathrm{C}$ ). D1 is overprinted by D2 structures related to a NW-SE trending open anticline. This phase is characterized by blueschist mineral associations, and corresponds to the quasi-isothermal decompression from a depth of $90 \mathrm{~km}$ (eclogitic conditions) up to $30-40 \mathrm{~km}$. The final exhumation phase of the Tso Morari unit is dominated by tectonic denudation and erosion (D3), associated with a slight temperature increase. Radiochronological analyses indicate that the UHP exhumation process began during the Eocene. Exhumation was fast during D1-D2 and slowed down through D3 in Oligocene time. The change in the deformation style from D1-D2 to D3 in the Tso Morari unit coincides with changes in the exhumation rates and in the metamorphic conditions. These changes may reflect the transition from an exhumation along the subduction plane in a serpentinized wedge, to the vertical uplift of the Tso Morari unit across the upper crust. 
Index terms : 8110 Continental tectonics, 3660 Metamorphic petrology, 8015 Local crustal structure, 9320 Asia

Key words : Exhumation processes, ultra-high pressure metamorphism, Himalaya, horizontal shortening, folding, India-Asia convergence

\section{Introduction}

High to Ultra-high pressure metamorphic rocks of continental or oceanic origins are always found in convergent zones [Ernst and Liou, 1999]. Some of these eclogitic metamorphic rocks formed under high pressure and low temperature conditions indicate that they have been buried in a subduction zone context [Platt, 1993]. The subsequent return of these well preserved eclogitic rocks to the Earth's surface often implies a rapid exhumation [e.g. Duchêne et al., 1997]. However, as they display different tectono-metamorphic evolutions [Cloos, 1982; Spalla et al., 1996], the exhumation processes still remain a matter of debate as various partly contradictory models exist: coaxial extension, associated with a detachment fault [Ruppel et al., 1988; Jolivet et al., 1996]; extensional collapse [Dewey et al., 1993]; thrusting towards the foreland [Argand, 1916; Steck et al., 1998]; buoyancy forces assisted by erosion and tectonic processes [Chemenda et al., 1996]; corner flow [Platt, 1993; Allemand and Lardeaux, 1997], or channel flow [Cloos, 1982; Guillot et al., 2000, 2001]; exhumation by extrusion within a soft zone of deformation compressed between two rigid blocks [Thompson et al., 1997a].

Each exhumation model predicts the nature of the contact between the high pressure (HP) or ultra-high pressure (UHP) unit and surrounding lower grade rocks, and the kinematics of penetrative structures. Detailed structural, petrological and geochronological analyses of HP to UHP rocks thus appear necessary to precise the exhumation processes of such rocks.

The outstanding preservation of petrologic and structural features in and around the coesite bearing eclogitic Tso Morari massif [Sachan et al., 2001], makes this area an ideal zone to study the exhumation processes of UHP rocks. 
The petrological and geochronological results have previously been published on the Tso Morari massif [de Sigoyer et al., 1997, 2000; Guillot et al., 1997; O'Brien et al., 2001, Sachan et al., 2001]. In this paper we will focus on the structural analysis of the UHP unit and its surrounding areas.

The synthesis of structural, petrological and geochronological studies will lead to a discussion on the exhumation processes of UHP rocks, which will be used as a basis for future modelling.

\section{Geological transect}

The investigated area is located in eastern Ladakh (northwest India), in the internal part of the Himalayan belt (Figure 1). It spreads from the Ladakh batholith to the north to the Indian continental margin to the south, between $78^{\circ} 25^{\prime} \mathrm{E}$ and $77^{\circ} 50^{\prime} \mathrm{E}$ of longitude and $34^{\circ} \mathrm{N}$ and $32^{\circ} 5^{\prime} \mathrm{N}$ of latitude (Fig.2).

In this study we highlight a new northeast-southwest geological transect from the Ladakh batholith to the Tethyan sedimentary cover of the Indian margin (Figure 3). Along this cross-section three domains are distinguished (a) the Ladakh Batholith and Indus Suture Zone, (b) the Tso Morari unit and (c) The Mata-Karzog unit.

\subsection{The Ladakh Batholith and Indus Suture Zone}

\section{(1) The Ladakh Batholith}

The Ladakh Batholith or Trans-Himalayan Batholith is located between the Shyok Suture Zone to the north and the Indus Suture Zone to the south. According to Bassoulet et al. [1983]; Reuber et al. [1987]; Mahéo et al. [2000]; Rolland et al. [2001] this calc-alkaline batholith corresponds to a volcanic arc, formed along the Asian margin during the northward subduction of the Neo-Tethys ocean from Lower Cretaceous to Early Eocene [Debon et al., 1986; Le Fort, 1989; Weinberg and Dunlap, 2000]. Before $75 \mathrm{Ma}$, the Ladakh arc was accreted onto the Asian margin creating a thick crustal zone [Rolland et al. 2002].

\section{(2) Indus Suture Zone}


The Indus Suture Zone is composed by six units, from north to south: (a) the Indus Sequence, (b) the Nindam Flysch, (c) the Nidar Ophiolite, (d) the Shergol Conglomerate, (e) the Drakkarpo unit, (f) the Ribil unit.

\section{(2a) The Indus Sequence}

The Indus sedimentary sequence was deposited in an episutural basin that evolved from a marine to a continental environment and recorded the closure of marine domain between the two converging continents. The sequence begins with Late Cretaceous detritic formations eroded from the Ladakh batholith [Van Haver, 1984; Mascle et al., 1986; Robertson, 2000]. They are followed by the Gongmaru-La formation, composed by red deltaic sediments and nummulitic Lower Eocene limestones accumulated on the Asian margin, [Blondeau et al., 1986; Garzanti et al., 1987]. The Middle to Upper Eocene Choksti conglomerate with stretched granodioritic and andesitic pebbles overlies the Gongmaru-La formation [Mascle et al., 1986]. Southwards, red continental pelites alternating with paleosoils and green conglomeratic sandstones lie in channels. They are typical of the Oligocene Nurla formation related to the erosion of the Indian continental margin [Baud et al., 1982].

\section{(2b) The Nindam Flysch}

The thick (hectometric to kilometric) Cenomano-Maastrichian Nindam Flysch consists of sandstones and pelitic rocks that derive from the volcano-clastic products of the Ladakh magmatic arc [Bassoullet et al., 1983; Robertson, 2000].

\section{(2c) The Nidar Ophiolite}

The ophiolite is well preserved and mainly unmetamorphosed (only local occurrence of chlorite suggests hydrothermal metamorphism). The base of the Nidar Ophiolite consists of 1000-m of well preserved pillow lava and basalt. A large dyke complex overlays the pillow lava. It is made of microgabbros infilled by doleritic dykes. Southwards, the dyke complex is replaced by a 1-km wide level of gabbros. Above the gabbros, lies serpentinites, within which one can distinguish cumulates of lower oceanic crust and mantle residue rocks [Guillot et al., 2000]. Geochemistry on the 
metabasalts [Thakur and Baht, 1983; de Sigoyer, 1998; Mahéo et al., 2000] suggests an intraoceanic arc setting that corresponds to the eastward equivalent of the Spontang Ophiolite (W Ladakh) (Figure 1).

\section{(2d) The Shergol Conglomerates}

The Shergol conglomerates thrusts over the Nidar Ophiolite (Figure 2 and 3), they lie in between the Nidar Ophiolite and the Drakkarpo unit [Mascle et al., 1986]. The sequence consists of coarse continental conglomerates with pebbles coming from the Nidar ophiolite, Drakkarpo, Ribil and Tso Morari unit. This formation corresponds to a post-collisional product of erosion of the internal Himalayan orogen. It is not directly dated in Ladakh, but similar Oligocene conglomerates in an identical structural position were observed in south Tibet [Van Haver, 1984; Colchen et al., 1987].

\section{(2e) The Drakkarpo unit}

The Drakkarpo unit (Figure 2) is $5 \mathrm{~km}$ wide. Its base consists of a 2000-m thick polygenic conglomerate composed by a matrix of schists, green sandstones, or calcareous slates in which lenses of tuffs, basalts, serpentinites, quartzites, micaschists and radiolarites are observed. The holes and fractures of the tuffs are filled with carbonates, chlorites and oxides suggesting hydrothermal metamorphism. These volcanic rocks have alkaline affinities, their geochemical features suggest an oceanic island (OIB) origin [Fuchs and Linner, 1997; de Sigoyer, 1998]. Thick white limestone typical of platform facies environment, probably Permian in age [Colchen et al., 1987; Corfield et al., 1999] is embedded in Upper Albian to Mid Cenomanien red sandstones [Fuchs and Linner, 1996]. The location of this unit, between the Nidar Ophiolite and the Indian margin, the succession of the different lithologies, and the geochemical data suggest that the Drakkarpo unit represents a remnant of former seamounts such as the Photang unit observed below the Spontang Ophiolite (Figure 1) [Colchen et al., 1987; Reuber et al., 1987; Corfield et al., 1999].

\section{(2f) The Ribil unit}

Southwards, the Drakkarpo unit thrusts over the Ribil unit metamorphosed under greenschist facies conditions (Figure 2, 3). The Ribil unit consists of agglomeratic slates, overlaid by reddish 
brown dolomite marbles, pyroxenes bearing basalts, and vesicular basalts. Brachiopod fragments, from the Upper Paleozoic (Upper Carboniferous to Permian) where found in the marbles by Fuchs and Linner [1996]. A similar succession of rocks is described in the basement of the Lamayuru formation [Colchen et al., 1994] suggesting that the Ribil unit may represent the distal part of the Indian continental margin. However, the geochemical analyses carried out on the basalts [de Sigoyer, 1998] show an alkaline OIB (Oceanic Island Basalt) origin, similar to those observed in the Drakkarpo unit. We interpret these both units as remnants of seamounts accreted on the Indian margin.

\subsection{The UHP Tso Morari unit}

The Tso Morari unit is one of the westernmost North Himalayan gneissic domes, but unlike the other domes, it is metamorphosed under UHP conditions. The Tso Morari unit (100 km * $50 \mathrm{~km})$ outcrops south of the Ribil unit (Figure 4). It has an elongated shape striking northwest-southeast (Figure 2, 3) [Thakur, 1983]. According to stratigraphic constraints, the Tso Morari unit represents a remnant tilted block of the distal Indian continental margin [Colchen et al., 1994; Steck et al., 1998]. In its central part, orthogneiss are intrusive into more or less deformed Cambro-Ordovician sediments [Trivedi et al., 1986; de Sigoyer, 1998, Girard and Bussy, 1999]. Some metabasic rocks are infilled in the orthogneiss and may be associated with the Ordovician magmatic event, as they present chemical continental affinities [de Sigoyer, 1998]. Towards the rims of the dome, the orthogneiss is overlaid by an Upper Carboniferous to Permian metasedimentary cover [Colchen et al., 1994; Fuchs and Linner, 1996], which consists of metapelites, metagreywackes, metacarbonates, reddshish Permian metadolomites and quartzites. Hectometric lenses of metabasic rocks are associated with the Permian dolomitic limestones, they show continental tholeiitic affinities like the Panjal traps [de Sigoyer, 1998], and are related to the Carboniferous-Permian rifting of the Neo-Tethys [Bassoullet et al., 1983; Honegger et al., 1982; Spencer and Gebauer, 1996].

An undeformed granite outcrops in the Polokongka La pass. According to geochemical data this granite forms part of the Cambro-Ordovician orthogneiss; $\mathrm{Sm} / \mathrm{Nd}$ (on apatite, garnet and whole rock [de Sigoyer, 1998]), Rb/Sr ([Trivedi et al., 1986]) and U-Pb (on zircon [Girard and Bussy, 
1999]) ages are respectively $458 \pm 14 \mathrm{Ma}, 487 \pm 25 \mathrm{Ma}$ and $479 \pm 2 \mathrm{Ma}$. Similar ordovician granite and orthogneiss are observed in the Nyimaling area [Stutz and Steck, 1986], they present a Gondwana affinity as many of them developed along the Indian continental margin [Le Fort et al., 1986].

The petrological observations and thermobarometrical estimates carried out on the Tso Morari metapelitic and metabasaltic rocks are detailed in Guillot et al. [1995]; de Sigoyer et al. [1997]; Guillot et al. [1997] de Sigoyer [1998], O’Brien et al. [2001] and Sachan et al. [2001]; (Figure 5, 6). Evidence of ultra-high pressure and relatively low-temperature metamorphism (20-25 kbar and 580 $\pm 60^{\circ} \mathrm{C}$ ) are deduced in the Tso Morari unit by the occurrence of coesite, garnet, omphacite, phengite, glaucophane and zoisite in the basic rocks [de Sigoyer et al., 1997; Sachan et al., 2001] and by the association of jadeite, garnet, chloritoide, phengite in the metapelites [Guillot et al., 1997]. In the orthogneiss the UHP metamorphic conditions are much more difficult to characterize as the mineral assemblage presents a high variance. Therefore changes in pressure and temperature conditions will mainly modify the composition of the coexisting mineral phases. However in the Tso Morari orthogneiss, the magmatic plagioclase and biotite have reacted at the expense of $\mathrm{Ca}$ rich garnet (Grossular 52\%), kyanite, phengite (with a $\mathrm{Si}^{4+}=3.36$ ) and zoisite, associated with rutile. This mineral assemblage is often described in other UHP orthogneiss as in the Gran Paradiso or Monte Rosa in the Alps [Le Goff and Ballèvre, 1990; Dal Piaz and Lombardo, 1986], and suggests that the orthogneiss underwent the same metamorphic conditions than the metasedimentary and metabasic rocks. These metamorphic conditions reveal the subduction of the Tso Morari unit, and consequently of the Indian margin down to a minimum depth of $90 \mathrm{~km}$ (Figure 5). During its exhumation up to 40-30 km depth the Tso Morari unit underwent isothermal decompression under blueschist facies conditions $\left(11 \pm 3 \mathrm{kbar} ; 580 \pm 50^{\circ} \mathrm{C}\right)$ as shown by the crystallization of secondary glaucophane, in metapelites on the eastern part of the unit [de Sigoyer et al., 1997; Guillot et al., 1997]. In the western part of the unit, calcic amphibole (and not glaucophane) and garnet crystallized in between omphacite and garnet in the metabasic rocks [de Sigoyer et al., 1997, O'Brien et al., 2001, Girard, 2001]. Staurolite associated with chlorite and phengite in the S2 plane reacted to give kyanite and biotite, in the metagraywackes, such a reaction implies a temperature increases (Figure 5, Plate 1) [Guillot et al., 1997]. Thermobarometrical studies carried out on these 
western rocks show a temperature increase up to $630 \pm 50^{\circ} \mathrm{C}$ under amphibolitic facies conditions at $30 \mathrm{~km}(9 \pm 3 \mathrm{kbar})$ depth. In all the rocks chlorite and white micas continued to crystallize in $\mathrm{C} 3$ shear bands under greenschist facies conditions during the end of the Tso Morari exhumation. The recrystallization of the eclogitic rocks into garnet bearing amphibolite and then under greenschist conditions is mainly observed in the southern and western part of the Tso Morari unit, while they are retrogressed under blueschist and greenschist facies conditions in the eastern part (Figure 5, 6).

\subsection{The Mata-Karzog unit}

South of the Tso Morari unit, some chromitic pods associated with serpentinites and basaltic lava crop out in the core of a synclinorium (Figure 2). As first suggested by Berthelsen [1953] and according to geochemical data these rocks represent a relict of an intra-oceanic arc ophiolite [Mahéo et al., 2000]. The Karzog Ophiolite may represent the southward continuity of the Nidar Ophiolite [Mahéo et al., 2000]; (Figure 3). Under the Karzog Ophiolite lies the Carboniferous to Permian sedimentary sequence of Mata [Berthelsen et al., 1953, Virdi et al., 1978]. South of Karzog village, the Mata-Rupshu granite is observed in the core of a recumbent north verging anticline. Trivedi et al. [1986] proposed a Rb-Sr age of $487 \pm 14$ Ma for the Mata-Rupshu granite, confirmed by a U-Pb zircon age of $482.5 \pm 1 \mathrm{Ma}$ [Girard and Bussy, 1999]. In the upper part of the Mata crest $(6275 \mathrm{~m})$, doleritic sills intrude the granite. South of the Mata-Rupshu granite, a thick normal metasedimentary cover is developed starting with reddish brown dolomitic slates, overlaid by dark slates, which show alternation of quartzitic and calcareous levels. In these latter levels, fragments of ammonites were found [Georges Mascle, pers. com.], and were described by Virdi et al. [1978] as Permian fossils.

In the Mata-Karzog unit no relics of eclogites were found. Magmatic pyroxene relics are still observed in the basic rocks located in the northern part of the unit, elsewhere these metabasic rocks have re-crystallized into actinolite, biotite, plagioclase, zoisite, chlorite, magnetite and carbonate. Such a mineral association is typical for upper greenschist to epidote amphibolite metamorphic facies (Figure 5) [de Sigoyer, 1998]. The lack of eclogitic rocks and the occurrence of magmatic relics in the basic lenses indicate that the Mata-Karzog unit has never undergone HP metamorphism. 
The major observation carried out on the different units of the studied area is the combination of strongly contrasted metamorphic and stratigraphic domains. The unmetamorphosed Indus Suture Zone (with Asian and oceanic affinities) is bounded by the UHP Tso Morari unit (with Indian affinities) which is bounded to the south with the weakly metamorphosed (upper greenschist conditions) Mata-Karzog unit (Figure 2, 3, 5, 6).

\section{Deformation pattern}

In order to understand the exhumation mechanisms of the UHP Tso Morari unit and the nature of the contacts between the three main domains, we compared the tectonic evolution of the Tso Morari unit with contiguous units. The bulk finite strain pattern and the principal directions of finite deformation in the three main domains are deduced from the structural observations. The numbering of deformational phases D1, D2 and D3 on the different units is propping on the Tso Morari unit evolution (Table 1). The geological description of the studied area shows a general northwest-southeast trending of the different units (Figure 7).

\subsection{Structural evolution of the Indus Suture Zone}

Observations:

The Indus Suture Zone is characterized by fan shape geometry with northeast and southwest verging structures, respectively north and south of this zone (Figure 3, 7).

(1) The Ladakh batholith is locally reworked by a post magmatic $\mathrm{N} 120^{\circ} / 40^{\circ} \mathrm{S}$ foliation plane, that bears a $\mathrm{N} 165^{\circ} / 35^{\circ}$ mineral lineation underlined by amphiboles. To the south the batholith is in stratigraphic contact with the Indus sequences, which are deformed by F1 south verging folds. These F1 folds are strongly overprinted by hectometer to kilometer northeast verging F2 folds. The $\mathrm{F} 2$ folds are syn-foliation, they have a $\mathrm{N} 120^{\circ} / 40^{\circ} \mathrm{S}$ axial plane and a $\mathrm{N} 135^{\circ} / 35^{\circ}$ axis.

To the south, the Indus Sequence is separated from the Nindam Flysch (Figure 3) by a steep south verging extensional fault $\left(\mathrm{N} 070^{\circ} / 80^{\circ} \mathrm{S}\right)$ with an oblique $\mathrm{N} 240^{\circ} / 50^{\circ}$ striae suggesting a strike- 
slip component. This brittle fault reworks an earlier northeastern verging thrust as described by Van Haver [1984] in western Ladakh.

Locally, evidences of recent northwest-southeast dextral strike-slip faults, parallel to the Karakorum fault are also observed in the Indus valley. They locally crosscut the Quaternary alluvial terraces.

(2) The Nindam Flysch first thrusts over the Nidar Ophiolite towards the southwest D1. Then north verging synfoliated F2 folds, similar to those observed in the Indus Sequence, redeformed the Nindam Flysch.

(3) The Nidar Ophiolite has been affected by a penetrative planar fabric D2 oriented $\mathrm{N} 150^{\circ} / 70^{\circ} \mathrm{S}$, associated to the formation of the large northeast verging folds with $\mathrm{N} 140^{\circ}$ fold axis and by top to the northeast thrust. This D2 deformation partly overturned the southern part of the ophiolite (Figure 3). At a regional scale, the Nidar Ophiolite shows a sigmoid shape, striking $\mathrm{N} 120^{\circ}$, suggesting that it has also recorded dextral strike slip movement compatible with the movement observed on the Karakorum fault to the north (Figure 1).

(4) The Oligocene Shergol conglomerates overthrust the Nidar Ophiolite towards the northeast.

(5) The Drakkarpo unit (Figure 2) extends along a N120-140 ${ }^{\circ}$ direction and shows a double verging structure (Figure 3). It overthrusts the Nidar Ophiolite towards the northeast, and the Ribil unit towards the southwest. Some reverse faults striking $\mathrm{N} 13540^{\circ} \mathrm{N}$ are observed close to the southern boundary of the Drakkarpo unit. They deformed the limestones and basalts levels and are overprinted by S2 foliation, they were probably active during D1.

In the Drakkarpo unit the alignment of white limestones can be observed in the landscape and in Spot images. This alignment is parallel to the N120-140 trending direction of the Drakkarpo unit, and to the F2 folds axis (La2) in the core of the unit $\left(\mathrm{N} 317^{\circ} / 20^{\circ}\right)$ (Figure 7). The F2 folds and the associated S2 foliation overprint a previous S1 foliation. The L2 mineral lineation is oriented $\mathrm{N} 120^{\circ} / 6^{\circ}$ in the southern part of the unit and $\mathrm{N} 080^{\circ} / 36^{\circ}$ in the northern part of the unit. S2 dips to 
the south in the northern part of the unit and to the north in the southern part, leading to the fan shape of this unit. On the southwestern border of the unit a L3 stretching lineation oriented N030 $/ 45^{\circ}$ locally developed on the main foliation plane. The northern contact of the Drakkarpo unit involves the Shergol conglomerates suggesting that thrusting toward the north was probably active after the Oligocene and could be related to D3 (Figure 3).

(6) In the Ribil unit the main structures are hectometer south verging synfoliated F1 folds with fold axis oriented $\mathrm{N} 322^{\circ} / 13^{\circ}$, associated with a northeast dipping foliation $\left(\mathrm{N} 135^{\circ} 40^{\circ} \mathrm{N}\right)$ and $\mathrm{L} 1$ lineation $\left(\mathrm{N} 060^{\circ} / 30^{\circ}\right)$. These folds are associated with shear planes showing top to the southwest thrusting movement (Figure 3). Few hundred meters before the Tso Morari unit extensional structures D2-3 appear. D2-3 structures are characterized by northeast dipping S/C structures, drag folds with axial plane oriented $\mathrm{N} 130^{\circ} / 25^{\circ} \mathrm{N}$, and late kink bands. The stretching lineation $\mathrm{L} 3$ is perpendicular to the border of the units, and is oriented $\mathrm{N} 030^{\circ}$. These structures are carried by chlorite and quartz assemblages suggesting greenschist facies metamorphic conditions during D2-3. Finally, a late brittle extensional fault dipping at about $60^{\circ}$ toward the northeast marks the boundary between the Ribil and Tso Morari units. This brittle fault belongs to the Zildat zone, which separates the weakly metamorphosed Indus Suture Zone from the UHP Tso Morari unit (Figure 4, $5,6)$. The D2-3 normal ductile structures are mainly observed in the footwall of the Zildat zone, in the Tso Morari unit.

\section{Interpretation:}

Regionally, the first deformation phase (D1) observed in the Indus Suture Zone corresponds to the southwards thrusting of this zone over the Indian continental margin. Relicts of the Nidar ophiolite are observed in the core of the Mata-Karzog synclinorium, suggesting the obduction of the Nidar ophiolite onto the Indian margin during D1 (Table 1). In contrast with the Spontang ophiolite that thrust over the Eocene sediments, the Karzog ophiolite lies above Permo-Carboniferous sediments. The Mesozoic cover of the Indian margin could have been scrapped off during the early subduction of the Tso Morari unit [Guillot et al., 2000]. 
The D2 phase is related to back-thrusting of the Indus Sequence and Drakkarpo unit towards the northeast, while the Ribil unit underwent ductile extension towards the northeast. The S2 pattern of the Indus Suture Zone is characterized by a S-shape curvature compatible with a dextral strike-slip movement. This S-shape of the foliation combined with the fan shape geometry of the Indus Suture Zone, of the Drakkarpo unit and with the asymmetric shape of the Nidar Ophiolite suggests a dextral transpressive regime in the Indus Suture Zone during D2.

D3 is mainly observed closed to the Tso Morari unit and is related to normal movements top towards the northeast under ductile and brittle conditions

In the studied area the global D1-D2 strain pattern is partitioned between a $\mathrm{N} 30^{\circ}$ direction of shortening and a $\mathrm{N} 120^{\circ}$ direction of dextral wrenching. This shortening direction is close to the

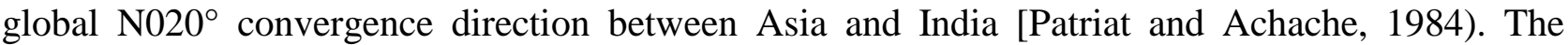
obliquity between the convergence direction and the shortening direction in the Indus Suture Zone may lead to strain partitioning, and explain the occurrence of dextral strike slip movement on the Indus Suture Zone. A hundred kilometres north of the Indus suture zone, the dextral strikeKarakorum fault, is still active (Figure 1).

\subsection{Structural evolution of the Tso Morari UHP unit}

Observations:

The Tso Morari unit has elongated dome geometry, corresponding to a double plunging anticline towards the northwest and southeast (Figure 2, 7) [Thakur, 1983]. The principal axis of this elongated dome has a NW-SE orientation and dips $10^{\circ}$ to the NW (Figure 7). According to this geometry the Tso Morari dome has a maximum thickness of $7 \mathrm{~km}$. The dome is characterized by a flat foliation S2 in its central part, which becomes steeper with opposite dipping directions on its borders (Figure 3). Two normal ductile shear zones bound the dome, the Zildat shear zone to the northeastern limb and the Karzog shear zone to the southwestern limb (Figure 3, 4).

Three main phases of ductile deformation are observed in this crystalline massif (Table 1). The first phase (D1) is only preserved in the central part of the unit. The second one (D2) is well developed all over the Tso Morari unit except on its border, where D3 has strongly overprinted it. The structures related to each phase of deformation were observed either in the orthogneiss, in 
metabasic or metapelitic rocks. Our structural study concerns mainly D2 and D3 events, which are clearly related to the exhumation of the UHP Tso Morari unit.

\section{D1 Deformation}

There is very few evidence of D1 structures (Table 1a, b, c), which are only observed in the northwestern part of the dome close to the Polokongka La (Figure 7). D1 is characterized by steep tight to isoclinal folds (F1) of centimetre to hectometre scale associated with a sub-vertical axial plane cleavage (S1), oriented $\mathrm{N} 050^{\circ} / 70^{\circ} \mathrm{NW}$ (Plate 1a). These folds deform the orthogneiss as well as the metabasic levels and the metasediments. The $\mathrm{S} 1$ foliation in the metabasic rocks is borne by eclogitic minerals, garnet and omphacite, (Plate 1b). The omphacites have recrystallized dynamically and define the foliation and the mineral lineation, showing that D1 was recorded under eclogitic facies conditions (Figure 6) [de Sigoyer et al., 1997]. In the metapelitic rocks D1 defines a kyanite, phengite, quartz foliation (Guillot et al., 1997).

\section{D2 Deformation (Plate 1a, c, d, e, Figure 7, Table 1)}

Recumbent isoclinal to open metric folds (F2) deforms the $\mathrm{S} 1$ foliation (Plate 1a, c). D2 is very penetrative and characterized the main deformation phase of the Tso Morari unit (Figure 3 and 7); D1 structures are transposed to shallow dipping S2-L2 structures. In the central part of the unit, the $\mathrm{S} 2$ schistosity is flat, the fold axis La2 strike of about $\mathrm{N} 130^{\circ}$, they are sub-horizontal and parallel to the mineral and stretching lineation (L2) (Figure 7). Toward the edges of the dome, the S2 foliation is steeper. The general trend of the S2 foliation defines the dome shape of the Tso Morari. On the border of the dome the L2 stretching lineation is perpendicular to the La2 fold axis along a N040 direction. In the northern limb of the dome centimetre to hectometre $\mathrm{Z}$ shape F2 folds are observed, whereas on the southern limb, the F2 folds have $\mathrm{S}$ shape. As the polarity of the series remains normal all over the Tso Morari dome, the F2 folds are south verging in the northern limb of the unit and north verging in its southern limb (Figure 3). These antagonistic fold verging between the limbs of the dome are confirmed by $60 \%$ (38 over 64) of unambiguous shear criteria (C/S structures) which shows top to the southwest sense of shear in the northern limb of the dome (Plate 1d), and top to the northeast sense of shear in the southern limb (Plate 1e). The C/S structures are associated 
with pressure shadows on the K-feldspar clasts in the orthogneiss which is a strongly lamined porphyric granite-mylonite, the shear criteria are of opposite sense in both side of the dome (Plate 1d) as well as in the metapelites. Asymmetric basic lenses also show top to the SW shear criteria in the northeastern limb and top to the NW shear criteria in the southern limb of the dome (Plate 1e). As we never observed evidence of superposition of these structures interpreted as D2 structures, we propose that the opposite sense of shear and opposite verging folds on both limbs of the Tso Morari dome correspond to a single deformation event.

In the core of fresh metabasic lenses the $\mathrm{S} 1$ eclogitic foliation (defined by garnet and dynamic crystallization of omphacite) (Plate $1 \mathrm{~b}$ ) is slightly replaced by blueschist mineral association while on the border of the lenses eclogitic minerals are mainly replaced by amphibolitic mineral assemblages. This suggested that the level of basic rocks were stretched and sheared during the blueschist D2 phase of deformation (Plate 1e). In the Fe-rich metapelitic rocks phengite and glaucophane define the L2 mineral lineation. The S2 foliation, which represents the axial surface of the F2 folds, is underlined by blueschist mineral associations. In the Mg-rich metapelites, $\mathrm{Mg}$ chlorite crystallized in the hinge of $\mathrm{F} 2$ folds at the expense of kyanite and phengite, $\mathrm{Mg}$-chlorite is frequently described in HP rocks, its crystallization at the hinge of the folds shows that the F2 folds were developed at the beginning of decompression (Plate 1c). These petrological observations suggest that D2 structures were recorded during the first part of the Tso Morari rock exhumation from eclogitic conditions down to blueschist metamorphic conditions (Figure 6).

\section{D3 Deformation}

In the central part of the dome, D2 structures are slightly overprinted by D3 shear planes (C3). The D3 structures are mainly localized on the borders of the dome in two kilometric wide zones defined as the Zildat normal shear zone to the north and the Karzog normal shear zone to the south (Figure 3, 4, 7). The Zildat normal shear zone represents the ductile northern boundary of the Tso Morari unit; it separates the UHP unit from the low-grade metamorphic Indus Suture Zone (Figure 3, 4). The Zildat normal shear zone follows the Zildat valley west of Sumdo village, and continues in the southern side of the Ribil valley, east of Sumdo (Figure 7). The footwall of this shear zone is 
located within the Tso Morari unit, it corresponds to a large kilometric deformed band characterized by northeast dipping S3/C3 structures. The shear planes trend N120/30 NE, S3 foliation plane bears a stretching lineation L3 oriented $\left(\mathrm{N} 065 / 30^{\circ}\right)$. F3 drag folds with fold axis La3 oriented $\mathrm{N} 345^{\circ} / 15^{\circ}$ are usually associated with the S3/C3 shear bands. Shear criteria indicate top to the northeast movement (Plate 1f, g). Within the Zildat normal shear zone, occur hectometric lenses of serpentinites (Figure 4). Geochemical analyses indicate the depleted mantle origin of the serpentines. The serpentinites were removed from the hydrated mantle wedge by the Tso Morari massif during its exhumation, suggesting that the Zildat normal shear zone was active since the beginning of the Tso Morari exhumation [Guillot et al., 2000; 2001]. Close to the contact with the Ribil unit, the $\mathrm{C} 3$ shear bands are underlined by phengites, chlorites, secondary chloritoid, albite and rare biotites in the metapelites, relics of glaucophanes are totally transformed into chlorite and albite. These indicate that D3 continue to develop under lower amphibolite to greenschist metamorphic conditions [Guillot et al., 1997]. This ductile shear zone is later crosscut by a steep normal brittle fault, striking northwest and dipping $60^{\circ} \mathrm{N}$ (Figure 4). This steep normal fault crosscut the gently NE dipping cleavage. In the hanging wall (Ribil unit) of the Zildat normal shear zone (Figure 3) few shear indicators are observed. The contrasted record of D3 deformation between the footwall and the hanging wall of the Zildat shear zone is interpreted as a consequence of a strong vertical motion of the UHP Tso Morari unit relative to the weakly metamorphosed Ribil unit. The southern limb of the Tso Morari unit is affected by a wide south dipping extensional ductile shear zone, more than five kilometers wide, the Karzog normal shear zone. This zone separates the Tso Morari unit from the less metamorphosed south Mata-Karzog unit. In this zone the S3 schistosity $\left(\mathrm{N} 070^{\circ} / 20^{\circ} \mathrm{SE}\right)$ bears a stretching lineation $\mathrm{L} 3\left(\mathrm{~N} 170^{\circ}\right)$ that is parallel to the $\mathrm{L} 2$ stretching lineation, and perpendicular to the C3 shear planes. The S3/C3 structures observed in the orthogneiss suggest top to the southwest movements (Plate 1h). The Karzog normal shear zone is cross cut by the late Peldo normal brittle fault (Figure 7). No serpentinites were found within the Karzog normal shear zone.

In the rest of the Tso Morari unit the $\mathrm{C} 3$ shear planes are mainly developed in the metagranites and metapelites (Plate 1f, g, h, i). In the orthogneiss, the C3 shear planes are observed on the border of the K-feldspar porphyroclasts (Plate $1 \mathrm{~g}, \mathrm{~h}$ ). In the metagraywackes fresh kyanite and biotite 
developed in $\mathrm{C} 3$ shear planes at the expense of staurolite, phengite and chlorite in the S2 foliation plane (Plate 1i), suggesting that these shear bands were developed under amphibolitic conditions during the exhumation of Tso Morari unit [Guillot et al., 1997]. Metabasic lenses were also sheared and fractured during D3 (Plate 1f). Along the fractures, the normal shear zone and on the borders of the basic lenses, amphibolitic mineral assemblages ( $\mathrm{Ca}$ amphibole and biotite) have crystallized at the expense of eclogitic and blueschist minerals [de Sigoyer et al., 1997]. All the steps from fresh eclogites to deeply recrystallized amphibolites are observed from the core to the border of the basic lenses or towards the normal C3 shear planes. The thermobarometrical estimates carried out on the amphibolitic assemblage of metasediments and metabasic rocks suggest a temperature of $630 \pm 30$ ${ }^{\circ} \mathrm{C}$ for a pressure of $9 \pm 1$ kbar [de Sigoyer et al., 1997; Guillot et al., 1997] (Figure 6).

Tilted kilometric blocks bounded by normal faults are also observed in the Tso Morari dome, they are north verging in the northern flank and south verging in the southern flank. Thus, the normal phase of deformation D3 was first ductile under amphibolitic (Plate 1f, $\mathrm{g} \mathrm{h}$, i) and greenschist facies conditions, then brittle.

Finally Steck et al. [1998] described Quaternary dome and basin structure in this area with a wavelength of 10 to $150 \mathrm{~km}$ for an amplitude of 3 to $5 \mathrm{~km}$. Many Quaternary faults are also observed, some of them are reported on the structural map (Figure 7). The Tso Morari and Kiagar Tso lake are located on conjugated faults [Berthelsen, 1953]. At Puga, close to Zildat normal zone, hot sulphur spring is situated on an active fault. Steck et al, [1998] attributed these Quaternary structures to an active dextral transpressional regime, that created N-S striking normal faults, NWSE striking dome and basin structures in a main shear zone, parallel to NW-SE striking Indus Suture zone. These quaternary structures may partly overturned previous structures.

\section{Interpretation}

The different stages of deformation described in the Tso Morari unit can be interpreted as a consequence of progressive deformation during the exhumation of this UHP unit (Table 1). The rare F1 upright folds observed suggest a stage of horizontal shortening under eclogitic conditions. During D2 (the most penetrative deformation phase), the development of the flat S2 foliation in the central part of the unit implies a component of vertical shortening. This flattening is associated with 
a NW-SE lineation L2, parallel to the La2 folds axis and to the long axe of the Tso Morari dome. These structures suggest a component of horizontal stretching during D2 along a NW-SE direction. On the borders of the dome the opposite vergence of the D2 structures toward the core of the unit can be interpreted as secondary structures of an N120-130 huge anticline compatible with a N020N30 direction of shortening [e.g. Burg, 1987; Burg and Podlachikov, 1999]. By contrast to Thakur [1983] and Steck et al. [1998] who have interpreted the Tso Morari dome as the result of a late compressional event, we propose that the dome geometry of the Tso Morari is an earlier compressional structure mainly developed during D2 in continuity with D1 horizontal shortening structures., The combination of previous petrological study with our interpretation of the D2 structures allow to propose a model for the first part of the Tso Morari exhumation. We propose that D2 structures reflect the exhumation of the Tso Morari unit, realized by a combination of vertical and horizontal component of displacements probably along the subduction plane up to 40$30 \mathrm{~km}$. The end of the exhumation is controlled by D3 structures, which were developed from ductile amphibolitic-greenschist facies (40-30 km depth) to the brittle conditions close to the surface. D3 structures are mainly localized on the borders of the dome and characterized by normal shear zones that suggest a local non-coaxial strain regime (Table 1). We proposed that the gently NE dipping cleavage in the footwall of the Zildat normal shear zone, and SW dipping cleavage in the footwall of the Karzog normal shear zone were formed in a zone of subvertical shortening below these two major low angle shear zones. At regional scale, the finite D3 strain pattern suggests a sub-vertical uplift of the Tso Morari dome across the upper crust associated with tectonic denudation and erosion (Figure 8). This strain evolution is very similar to the strain evolution recorded by the Kangmar dome in southern Tibet [Lee et al., 2000]. The D3 shear structures could have been developed deeper within the Zildat zone in order to accommodate the relative motion of the Tso Morari with its surroundings. The evolution from D1 to D3 during the Tso Morari exhumation may reflect the transition from an exhumation along the subduction plane, in a serpentinized channel toward a vertical uplift across the upper crust (or the accretionnary wedge) (Figure 8). 


\subsection{Structural evolution of the Mata-Karzog unit}

\section{Observations:}

As discussed previously, the occurrence of chromitic pods and basalts at Karzog suggest the obduction of the Nidar Ophiolite on the Mata sequence (Figure 2, Table 1). The contact of the Karzog ophiolitic complex with the Mata sediments is concordant and strongly deformed and is interpreted as a tectonic contact. This obduction is considered as the first phase of deformation D1 in the Mata unit observed nowhere else than in Karzog. On the contrary D2 structures can be observed in the whole Mata unit. The striking of S2 foliation in the Mata unit is slightly discordant from the S2 foliation in the Tso Morari unit. S2 foliation dips southwards and has been developed as an axial surface structure for the ductile recumbent F2 folds (Figure 7). Asymmetric (F2) folds deformed the sedimentary sequence of Mata and the Karzog ophiolite, as the Karzog ophiolite lies in the core of a synclinorium. The sedimentary sequence is normal above the Mata granite [Mascle, pers. com. 1997] suggesting that the F2 folds are NE verging. The fold axes strike of about N120 in the northern part of the unit, and are along a N045 direction in the southern part (Figure 7). The stretching lineation L2 strikes $\mathrm{N} 160^{\circ}$ in the northern part of the unit and is oriented $\mathrm{N} 020^{\circ}$ in the southern part. The Mata-Rupshu granite is not deformed in its central part, but the upper and lower contacts of the granite are mylonitic zones, with top to the north thrusting shear criteria on the lower contact. The mylonitic zones localized the deformation between rocks of different competence (granite and sediments) In the basic rocks metamorphic minerals, as zoisite actinolite and biotite, bear the S2 cleavage, and suggest upper greenschist to epidote-actinolite amphibolite conditions during D2 (Figure 5, 6) [de Sigoyer, 1998]. Later, S3/C3 shear bands, showing top to the SW extensional movements overprinted the D2 structures. These extensional shear bands are mostly developed in the southern part of the unit, close to the Phirse valley, where a F3 generation of SW verging folds are observed. They correspond to top to the SW extensional motion of the Spiti sedimentary cover relative to the Mata unit (Table 1). Chlorite and micas underline D3 structures, showing that D3 began under greenschist facies conditions and continues under brittle conditions.

All the structures described in the Mata-Karzog unit were disturbed and rotated by a late fault network still active today. According to satellite images, this fault network is related to the 
formation of $\mathrm{N}-\mathrm{S}$ pull apart basins. The $\mathrm{N} 080^{\circ}$ dextral strike slip fault that cross cut the Tso Morari lake, could be directly related to the present day activity of the dextral Karakorum fault (Figure 1, 2, 7).

\section{Interpretation}

The Mata-Karzog unit is separated from the Tso Morari unit by the south dipping Karzog normal shear zone, this unit lies structurally over the Tso Morari unit. This observation is consistent with the metamorphic conditions recorded by these two domains (UHP in the Tso Morari unit, upper greenschist conditions in the Mata unit). After the ophiolite obduction, the Mata-Karzog unit was deformed by D2-D3 phases (Table 1). The north verging F2 folds observed in this domain, can be compared to those observed in the southern limb of the Tso Morari unit. They are all compatible with a $\mathrm{N} 030^{\circ}$ direction of shortening, as observed elsewhere in the studied area (Figure 7). However, in the Tso Morari unit D2 structures were developed under blueschist conditions, whereas greenschist metamorphic conditions were recorded during D2 in the Mata-Karzog unit. D2 structures were not recorded at the same structural level in Mata and Tso Morari units. The late D3 phase that overprinted the F2 folds in the Mata unit may be partly contemporaneous to the extensional D3 deformation phase recorded by the Tso Morari unit. The bulk D2 deformation recorded in the Mata unit after the ophiolite obduction can be explained by the pinching of this unit between the Indian convergent plate and the Tso Morari unit when this later was coming up through the surface. At the end of the Tso Morari exhumation, the Mata unit slides southwards during D3. Note that all the structures in the Mata-Karzog unit have opposite vergence by comparison to the structures observed in the Ribil unit, north of the Tso Morari unit (Table 1, Figure 3, 7). Thus, at the scale of the studied area, the bulk strain pattern is compatible with a NE-SW direction of horizontal shortening from the ophiolite obduction to the D2 phase. It was followed by extensional tectonics during D3 corresponding to the tectonic denudation and erosion of the whole area, which is associated locally (on the Zildat and Karzog normal shear zones) with vertical shortening (Table 1, Figure 3, 7).

\section{Timing of the deformations}


The bulk strain pattern emphasizes that the Tso Morari unit and the surrounding units have undergone a synchronous evolution only since D3 deformation phase. Previous deformations were independent in the different units. The first phase of deformation in the weakly metamorphic units (Indus Suture Zone and Mata unit) is related to the obduction of the Nidar Ophiolite onto the Drakkarpo and Ribil oceanic islands and on the Indian Margin (Mata unit). This obduction may have occurred during Eocene times as suggested by the ${ }^{40} \mathrm{Ar} /{ }^{39} \mathrm{Ar}$ age at $50 \mathrm{Ma}$ obtained on amphibole from the Karzog ophiolite [Mahéo and Villa pers. Com]. The timing of D2-D3 in the Indus sequence is estimated in the western part of Ladakh at about 40-35 Ma by Van Haver et al, [1986], on the basis of K/Ar cooling ages. The occurrence of the Oligocene Shergol conglomerates in the tectonic contact between the Nidar Ophiolite and the Drakkarpo unit shows that D3 was still active during and/or after Oligocene times.

Schlup et al. [2001] report fission track ages in the Mata unit at about $45 \pm 2 \mathrm{Ma}$ on zircon and $40 \pm 3 \mathrm{Ma}$ on apatite. The Mata unit was then at shallow crustal level at the end of Eocene times (Figure 8).

In the Tso Morari unit, D1 recorded the eclogitization and is dated at about $55 \pm 6 \mathrm{Ma}$ (Paleocene/Eocene boundary) by $\mathrm{Lu} / \mathrm{Hf}, \mathrm{Sm} / \mathrm{Nd}$ and $\mathrm{U} / \mathrm{Pb}$ geochronology on eclogitic mineral assemblages (Figure 6, 8) [de Sigoyer et al., 2000]. The transition from D2 to D3 occurred during the transition from blueschist to amphibolitic metamorphic conditions. The amphibolitic minerals have been dated at about $47 \pm 2 \mathrm{Ma}$ (Lower Eocene) by $\mathrm{Sm} / \mathrm{Nd}, \mathrm{Rb} / \mathrm{Sr}$ and $\mathrm{Ar} / \mathrm{Ar}$ geochronology (Figure 6) [de Sigoyer et al., 2000]. Thus, D2 occurred between 55 and before 47 Ma. Finally $40 \quad 39$

Ar/ Ar age of $30 \pm 1 \mathrm{Ma}$ (Oligocene) have been obtained on newly crystallized biotites and muscovites sampled in metagraywackes of the western part of the massif [de Sigoyer et al., 2000]. In the rest of the unit, fission track ages on zircon, between $40 \pm 2$ and $34 \pm 2 \mathrm{Ma}$, and on apatite, between $24 \pm 2$ and $8 \pm 2 \mathrm{Ma}$ are reported by Schlup et al. [2001]. The youngest apatite fission track ages were obtained in the Zildat normal shear zone, indicating that the normal fault was recently active [Schlup et al., 2001]. The ${ }^{40} \mathrm{Ar} /{ }^{39}$ Ar age and fission track ages confirm that the Tso Morari unit was already exhumed up to upper crustal levels by Upper Eocene to Lower Oligocene times (Figure 6, 8). 


\section{Exhumation processes in the Himalayan context}

Combining the ages obtained on the Tso Morari massif and converting the pressures to depth, yield exhumation rates greater than $7 \mathrm{~mm} / \mathrm{yr}$ for the first part of exhumation (between 90 to $30 \mathrm{~km}$ ) (Figure 6, 8) [de Sigoyer et al., 2000]. This first part of exhumation took place during the Lower Eocene (between 55 and $47 \mathrm{Ma}$ ). It was mainly controlled by the D2 deformation. Petrological data shows that this part of exhumation was quasi isothermal [de Sigoyer et al., 1997, Guillot et al., 1997] (Figure 6, 8), and occurred within a partially serpentinized mantle wedge [Guillot et al., 2000; 2001]. Paleomagnetic data on the Indian ocean and oceanic sediments show that during the Lower Eocene the convergent rate between India and Asia was superior than $10 \mathrm{~cm} / \mathrm{yr}$, suggesting that continental subduction was still active and rapid at this time [Klootwijk et al., 1992; Guillot et al., 2003]. The beginning of continental erosion is dated at 52 Ma by Garzanti et al. [1987] in the northwest Himalaya. Therefore the first part of the Tso Morari exhumation associated with rapid convergent rate was realized without significant erosion [de Sigoyer et al., 2000; Guillot et al., 2003].

From Upper Eocene to Oligocene, the Tso Morari unit was exhumed from 30 to $10 \mathrm{~km}$ depth with slower exhumation rate $(1.2 \mathrm{~mm} / \mathrm{yr})$. This second part of exhumation is controlled by the D3 normal structures. At the Himalayan scale, this period corresponds to a decrease of the convergent rate between India and Asia (from 10 to $5 \mathrm{~cm} / \mathrm{y}$ after $50 \mathrm{Ma}$ ) [Patriat and Achache, 1984]. This decrease is due to the thickening of the Himalayan wedge by the underthrusting of the Higher Himalayan Crystallines under the internal zone (Figure 8) [Treloar et al., 1989; de Sigoyer et al., 2000]. According to numerical modelling [Jamieson et al. 1996], a simple decrease of the convergent rate associated with a progressive thickening of a collision zone can explain the temperature increase recorded in the internal part of the belt at this time, as it was recorded by the Tso Morari unit. Goffé et al. [2003] show that the rocks type accreted in the wedge has important effects on thermal regime of orogenic wedge. Before the subduction of the Indian margin only oceanic crust and sediments were subducted explaining the low temperature metamorphism recorded by the Tso Morari UHP unit, whereas during the exhumation of the Tso Morari higher temperature was recorded due to the accretion of granitic material in the wedge, with higher 
radioactive heat production. In contrast, Chemenda et al. [2000] and Guillot et al. [2003] propose that the break-off of the Indian continental slab with the previously attached subducted oceanic lithosphere, could explain the heating of the internal zone. Whatever the cause of the slight temperature increase, the last part of the Tso Morari exhumation is realized by vertical extrusion associated with tectonic denudation and substantial erosion.

\section{What is the motor of the exhumation?}

The different phases of deformation recorded in the Tso Morari unit imply several exhumation processes, activated at successive structural levels. The underthrusting of the buoyant Higher Himalayan Crystallines unit below the Tso Morari unit from Middle Eocene to Oligocene, can easily explain the end of the Tso Morari unit exhumation by underplating and consequently tectonic denudation as observed in the internal part of accretionary prism [Platt, 1986; Goncalvez et al., 2000; Rolland et al., 2000] (Figure 8). However problems remain in understanding the beginning of the Tso Morari unit exhumation from 90 to $30 \mathrm{~km}$ depth. In the following, we will confront our data to the classical models of exhumation.

The scarcity of eclogitic rocks in the Himalayas and the quickness of the first part of exhumation of these eclogitic rocks ( $>7 \mathrm{~mm} / \mathrm{yr}$ ) show that erosion or isostatic reequilibration cannot explain the exhumation of the Tso Morari unit (Duchêne et al., 1997). The relatively low temperature $(<630 \pm$ $50^{\circ} \mathrm{C}$ ) recorded during the decompression of the Tso Morari unit and the geodynamical context are inconsistent with an exhumation ruled by extensional collapse [Dewey et al., 1993].

Buoyancy forces have been classically admitted as the major motor to exhume HP to UHP rocks [England and Richardson, 1977; Chemenda et al., 1996; 2000; Ernst and Liou, 1999]. However, Henry et al. [1997] show that the density of an eclogitized upper or intermediate continental crust $\left(3.06-3.31 \mathrm{~g} . \mathrm{cm}^{-3}\right)$ is close to the density of the mantle $\left(3.3 \mathrm{g.cm}{ }^{-3}\right)$. In the Tso Morari unit most of the rocks were recrystallized under eclogitic conditions unless some orthogneiss and granites, which are partly preserved from eclogitization, we can then assume a density of $2.9-3 \mathrm{~g} . \mathrm{cm}^{-3}$ for the whole HP massif. Cloos [1993] shows that the subduction of a lithospheric slab is possible only if 
the difference of density between the mantle and the subducted slab is greater than $10 \%$. If the exhumation of an eclogitic massif across the mantle is only ruled by buoyancy forces, a similar density difference of $10 \%$ should be expected between the exhumed massif and the mantle to initiated the exhumation. The analogical modelling of Chemenda et al. (1996) show that the exhumation of eclogitized terrains by buoyancy forces is possible only if a thick piston of buoyant (unmetamorphosed) continental crust push the UHP rocks towards the surface. As the Tso Morari unit represents a small portion of the upper crust $(100 * 50 * 7 \mathrm{~km})$ the buoyancy forces were probably not the only motor for the exhumation of this UHP massif.

The symmetry of the structures observed in the Tso Morari dome and in the surroundings and the direction of L2 lineation parallel to the long axe of the Tso Morari dome argue against an exhumation by nappes thrusting towards the foreland as suggested by Steck et al. (1998).

The model of exhumation in an accretionary sedimentary prism by corner flow is very efficient to explain the rapid syn-convergent exhumation of HP rocks located at the rear of the bulk accretionary prism [Platt, 1986; Allemand and Lardeaux, 1997]. The location of the Tso Morari unit close to the paleo-subduction plane, between the suture zone and the Indian shelf at the rear of orogenic prism, argues for this model. The dynamic of the corner flow model is governed by underplating. Nobody knows what is under the Tso Morari massif, neither if there was some underplating below the Tso Morari at the beginning of its exhumation, i.e. before Upper Eocene. On the other hand many observations support the channel flow model. The serpentinized rocks observed around the Tso Morari dome, within the Zildat ductile extensional fault have a lower density $\left(2.5 \mathrm{g.cm}^{-3}\right)$ than the eclogitic rocks and than the mantle wedge, a low coefficient of $19 \quad-1$

viscosity of about $10 \mathrm{~Pa} . \mathrm{s}$ at $550{ }^{\circ} \mathrm{C}$ [Carter and Tsenn, 1987], and low coefficient of friction $\left(\mu_{\mathrm{i}} \sim 0.15-0.3\right)$ [Escartin et al., 2001]. The presence of serpentines even in small amounts, allow the localization of deformation. As proposed by Guillot et al., [2000], the serpentines have probably played a leading role in the exhumation of the UHP Tso Morari dome acting as a lubricant in the mantle wedge. In this model, the exhumation within a low-viscosity channel is effectively controlled by a hydrodynamic return flow along the subducting plate [Cloos, 1982; 1986]. The Tso Morari dome could be exhumed as a rigid UHP unit embedded in light and soft serpentinites seamounts as observed today in the Mariana zone [Yamamoto, 1995]. Moreover, Guillot et al. 
[2001] show that the low normal deviatoric stress (few 10's of MPa) developed at the interface between the rigid subducting plate and the low-viscosity serpentinized wedge can produce a hydrodynamic return flow necessary to move back up an eclogitic unit. This normal stress could be also responsible to the development of the D1 and D2 structures observed within the Tso Morari unit, parallel to the slab surface. The onset of the Tso Morari exhumation is rapid and occurs along the subduction plane allowing a part of lateral movement (associated with the vertical component) as it is deduced form this study. In contrast the extensional structures developed closer to the surface are associated with a decrease of the exhumation rate. The changes in the Tso Morari exhumation rate and in its metamorphic conditions coincide with changes of the deformation phase and with the variation of the India-Asia convergence rate. This observation also suggests that boundary forces developed at the interface between the subducting plate and the mantle wedge have effectively a strong control on the exhumation of high- to ultra-pressure rocks.

It is noticeable that in Himalaya, eclogitic rocks have only been yet described around the NW syntaxis in Pakistan and Ladakh [Pognante and Spencer, 1991; Le Fort et al., 1997; O'Brien et al., 2001]. The scarcity of eclogitic rocks in Himalaya could be either due to a lack of knowledge of the internal zone or related to the obliquity of the convergence between Indian and Asian plates along the western syntaxis [Seeber and Pêcher, 1998]. The strain partitioning developed by this obliquity and emphasized in the western syntaxis by the active Karakorum fault and also by the earlier dextral motion deduced from this study in the Indus suture zone, has probably helped the exhumation of the Tso Morari. As suggested by numerical modelling [Fossen et al., 1998; Thompson et al., 1997a and b] the obliquity of the convergence, and the strain partitioning lead by this obliquity plays a major role in the vertical motion of HP to UHP rocks.

\section{Concluding remarks}

As suggested 10 years before by John Platt [1993] there is no single mechanism that can explain the exhumation of all high-pressure terrains. Today two main hypotheses are developed concerning the motor of the exhumation; some modelling proposed that volume forces acted as the motor of the exhumation whereas for other, exhumation is ruled by the forces acting on the boundaries of the 
deformed system. Our geological study on a natural example shows that boundary forces and velocity change at the lithospheric plate scale controlled in this case the exhumation of the UHP massif associated with tectonic denudation. However most of these high-pressure rocks have a sedimentological or granitic protolith suggesting that buoyancy forces also participated to exhumation processes.

Acknowledgements. We kindly acknowledge the financial support of the CNRS-INSU by the IDYL-HIMALAYA program. Discussions on the structural evolution of the Himalayan belt and on exhumation processes with A. Pêcher and G. Mascle in the field, J-P. Burg, P. Allemand, J-M. Lardeaux and J. Platt were very stimulating. A. Pfifner provided careful reviews that greatly improved the manuscript.

\section{References}

Allemand, P., and J.M. Lardeaux, Strain partitioning and metamorphism in a deformable orogenic wedge: application to the Alpine belt, Tectonophysics, 280, 157-169, 1997.

Argand, E., Sur l'arc des Alpes Occidentales, Eclog. geol. Helv., 14, 145-204, 1916.

Bassoullet, J.P., M. Colchen, T. Juteau, J. Marcoux, G. Mascle, and G. Reibel, Geological studies in the Indus suture zone of Ladakh (Himalayas), in: contribution to Himalayan Geology, vol. 2, edited by Gupta,Indust. Publ. Corp., Dehli, 96-124, 1983.

Baud, A., R. Arn, P. Bugnon, A. Crisinel, E. Dolivo, J.G. Esther, J.G. Hammerschlang, M. Marthaler, H. Masson, and A. Steck, Le contact Gondwana-peri-Gondwana dans le Zanskar oriental (Ladakh, Himalaya), Bull. Soc. géol. Fr., 24, 341-361, 1982.

Berthelsen, A., On the geology of the Rupshu district, NW Himalaya, Medd. fra. Dansk. Geol. Forening Kobenkhavn, 12, 350-415, 1953.

Besse, J., V. Courtillot, J.P. Pozzi, M. Westphal, and Y.X. Zhou, Paleomagnetic estimates of crustal shortening in the Himalayan thrusts and Zangbo suture, Nature, 311, 621-626, 1984.

Blondeau, A., J.P. Bassoullet, M. Colchen, T.L. Han, J. Marcoux, G. Mascle, and T. Van Haver, Disparition des formations marines à l'Éocène inférieur en Himalaya, Mémoire, Nancy, 47, 103-111, 1986. 
Burg, J.P., Regional shear variation in relation to diapirism and folding, Journal of Structural Geology, 9, 8, 925-934, 1987.

Burg, J.P., J.L. Bodinier, S. Chaudhry, S. Hussain, and H. Dawood, Infra-arc mantle-crust transition and intra-arc mantle diapirs in the Kohistan complex (Pakisdtani Himalaya): petrostructural evidence, Terra Nova, 10, 74-80, 1998.

Burg, J.P., and Y. Podladchikov, Lithospheric scale folding: numerical modelling and application to the himalayan syntaxes, Intern. J. Earth Sci., 88, 190-200, 1999.

Carter, N., and M. Tsenn, Flow properties of continental lithosphere, Tectonophysics, 136, 27-63, 1987.

Chemenda, A., J.P. Burg, and M. Mattauer, Evolutionary model of the Himalaya-Tibet system : geopoem based on new modelling, geological and geophysical data, Earth Planet. Sci. Lett., 174, 397-409, 2000.

Chemenda, A.I., M. Mattauer, and A. Bokun, Continental subduction and a mechanism for exhumation of high-pressure metamorphic rocks: new modeling and filed data from Oman, Earth Planet. Sci. Lett., 143, 173-185, 1996.

Cloos, M., Flow melanges : numerical modelling and geological constraints on their origin in the Franciscan subduction complex, Geol. Soc. Am. Bull., 93, 330-345, 1982.

Cloos, M., Blueschists in the Franciscan complex of california : Petrotectonic constraints on uplift mechanisms, Geol. Soc. Am. Bull, 164, 77-93, 1986.

Cloos, M., Lithospheric buoyancy and collisional orogenesis : Subduction of oceanic plateaus, continental margins, island arc, spreading ridges, and seamonts., Geol. Soc. Am. Bull., 105, 715-737, 1993.

Colchen, M., G. Mascle, and G. Delaygue, Lithostratigraphy and age of the formations in the Tso Morari dome, 9th Himalayan-Karakoram-Tibet worshop, Kathmandu, Abstract volume, Geol. Soc. Nepal, 1994.

Colchen, M., I. Reuber, J.P. Bassoullet, J.P. Belier, A. Blondeau, M. Lys, and P. De Wever, Données biostratigraphiques sur les mélanges ophiolitiques du Zanskar, Himalaya du Ladakh, Compte Rendus Acad. Sci., 305, 403-406, 1987. 
Corfield, R.I., M. Searle, and R.G. Owen, Photang thrustsheet: an accretionary complex structurally below the Spontang ophiolite constraining timing and tectonic environment of ophiolite obduction, ladakh, Himalaya, Geol. Soc. London, 156, 1031-1044, 1999.

Dal Piaz, G.V., and B. Lombardo, Early-alpine eclogite metamorphism in the penninic Monte Rosa-Gran Paradiso basement nappes of the northwestern Alps., In "Blueschists and eclogites", Geol. Soc. Am. Mem., 164, 249-265, 1986.

de Sigoyer, J., Mécanismes d'exhumation des roches de haute pression basse température, en contexte de convergence continentale (Tso Morari, NO Himalaya), Ph.D. thesis, Univ. Claude Bernard, Lyon, France, 1998.

de Sigoyer, J., V. Chavagnac, J. Blichert-Toft, I.M. Villa, B. Luais, S. Guillot, M. Cosca, and G. Mascle, Dating the Indian continental subdcution and collisional thickening in the northwest Himalaya: multichronology of the Tso Morari eclogites, Geology, 28, 487-490, 2000.

de Sigoyer, J., S. Guillot, J.M. Lardeaux, and G. Mascle, Glaucophane-bearing eclogites in the Tso Morari dome (eastern Ladakh, NW Himalaya), Europ. J. Miner., 9, 1073-1083, 1997.

Debon, F., P. Le Fort, S.M.F. Sheppard, and J. Sonet, The four plutonic belt of the Transhimalaya-Himalaya : a chemical, mineralogical, isotopic and chronological synthesis along a Tibet-Nepal section, J. Petrol., 27, 219-250, 1986.

Dewey, J.F., P.D. Ryan, and T.B. Andersen, Orogenic uplift and collapse, crustal thickness, fabrics and metamorphic phases changes: the role of eclogites, Magmatic Processes and Plate tectonics, edited by H. M. Prochard, T. Alabaster, N. B. W. Harris and C. R. Neary, Geol. Soc. Sp. Pub. pp. 325-343, 1993.

Duchêne, S., J.M. Lardeaux, and F. Albarede, Exhumation of eclogites: Insights from retrograde depth-time path analysis, Tectonophysics, 280, 125-140, 1997.

England, P.C., and S.W. Richardson, The influence of erosion upon mineral facies of rocks from different metamorphic environments, J. Geol. Soc. London, 134, 201-213, 1977.

Ernst, W. G. \& Liou, J. G, Overview of UHP metamorphism and tectonics in well-studied collisional orogens. International Geology Reviews, 41, 477-493, 1999.

Escartin, J., G. Hirth, and B. Evans, Strength of slightly serpentinized peridotites; implications for the tectonics of oceanic lithosphere, Geology (Boulder), 29, 1023-1026, 2001. 
Fossen, H., and B. Tikoff, Extented models of transpression and transtension, and applications to tectonic settings, In : Holdlsworth, R.E., Strachan, R.A., Dewey, J.F. (eds), Continental Transpressional and Transtensional Tectonics, Geol. Soc. Sp. Pub., 135, 15-33, 1998.

Fuchs, G., and M. Linner, On the geology of the Suture Zone and Tso Morari Dome in Eastern Ladakh (Himalaya), Jahrbuch Geologish. Bundesanstalt, 139, 191-207, 1996.

Fuchs, G., and M. Linner, Multiphase tectonics in the Indus suture zone of eastern Ladakh, 12th Himalayan Karakorum Tibet, workshop, 33-35, 1997.

Garzanti, E., A. Baud, and G. Mascle, Sedimentary record of the northward flight of India and its collision with Eurasia (Ladakh Himalaya, India), Geodinamica Acta, 1, 297-312, 1987.

Girard, M., and F. Bussy, Late Pan-African magmatism in NW Himalaya: new geochronological and geochemical data from the Orovician Tso Morari metagranites (Ladakh, NW Himalaya), Schweiz. Mineral. Petrogr. Mitt., 79, 399-417, 1999.

Girard, M., Metamorphism and tectonics of the transition between non metamorphic Tethyan Himalaya sediments abd the North Himalayan Crystalline Zone (Rupshu area, NW India), thesis 100 pp., Univer. Lausanne, 2001.

Goffé, B., Bousquet, R., Henry, P. and X. Le Pichon, Effect of the chemical composition of the crust on the metamorphic evolution of orogenic wedges, J. metamorphic Geol., 21, 123-141, 2003

Goncalvez, P., Guillot, S., Nicollet, C. and Lardeaux, J. M., Thrusting and sinistral wrenching in a pre-Eocene carribean accretionary wedge (Samana pensinsula -Dominican Republic). Geodinamica Acta, 13, 119-132, 2000.

Guillot, S., J.M. Lardeaux, G. Mascle, and M. Colchen, Un nouveau témoin du métamorphisme de haute-pression dans la chaîne himalayenne : les éclogites rétromorphosées du Dôme du Tso Morari, (Est Ladakh, Himalaya), Compte Rendus Acad. Sci., t.320,série II a, 931936, 1995.

Guillot, S., J. de Sigoyer, J.M. Lardeaux, and G. Mascle, Eclogitic metasediments from the Tso Morari area (Ladakh, Himalaya): evidence for continental subduction during India-Asia convergence, Contrib. Miner. Petro., 128, 197-212, 1997. 
Guillot, S., K. Hattori, and J. Sigoyer de, Mantle wedge serpentinization and exhumation of eclogites: insights from eastern Ladakh, northwest Himalaya, Geology, 28, 199-202, 2000.

Guillot, S., K.H. Hattori, J. de Sigoyer, T. Nägler, and A.L. Auzende, Evidence of hydration of the mantle wedge and its role in the exhumation of eclogites, Earth Planet. Sci. Lett., 193, 115-127, 2001.

Guillot S., Garzanti, G., Baratoux D., Marquer D.,Mahéo, G., de Sigoyer J., Reconstructing the total shortening history of the NW Himalaya, Geochem. Geophys. Geosyst., 4(1), XXXX, doi:10.1029/2002GC000484, 2003.

Henry, P., X. Le Pichon, B. Goffé, Kinematic, thermal and petrological model of the Himalayas; constraints related to metamorphism within the underthrust Indian crust and topographic elevation, Tectonophysics, 273, 31-56, 1997.

Honegger, K., V. Dietrich, W. Frank, A. Gansser, M. Thöni, and V. Trommsdorff, Magmatism and metamorphism in the Ladakh Himalayas (the Indus-Tsangpo suture zone)., Earth Planet. Sci. Lett., 60, 253-292, 1982.

Jamieson, R.A., C. Beaumont, J. Hamilton, and P. Fullsack, Tectonic assembly of inverted metamorphic sequences, Geology, 24, 839-842, 1996.

Jolivet, L., B. Goffé, P. Monié, C. Truffert-Luxey, M. Patriat, and M. Bonneau, Miocene detachment in Crete and exhumation P-T-t paths of High-pressure metamorphic rocks, Tectonics, 15, 1129-1153, 1996.

Klootwijk, C.T., J.S. Gee, J.W. Peirce, G.M. Smith, and P.L. McFadden, An early India-Asia contact: paleomagnetic constraints from Ninetyeast Ridge, ODP Leg 121, Geology, 20, 395-398, 1992.

Lee, J., B. Hacker, W.S. Dinklage, Y. Wank, P. Gans, A. Calvert, J. Wan, W. Chen, A.E. Blythe, and W. Mc Clelland, Evolution of the Kangmar dome, southern Tibet: structural, petrologic and thermochronologic constraints, Tectonics, 19, 872-895, 2000.

Le Fort, P., The Himalayan orogenic segment, In "Tectonic evolution of the Tethyan region", A.M.C. Sengör(ed.), Kluwer Academic Press, 259, 289-386, 1989. 
Le Fort, P., F. Debon, A. Pêcher, and J.V.P. Sonet, The 500 Ma magmatic event in alpine southern Asia, a thermal episode at Gondwana scale, In: Evolution des domaines orogéniques d'Asie méridionale (de la Turquie à l'Indonésie), P. Le Fort, M. Colchen \& C. Montenat eds, Sci. de la Terre, Nancy, 47, 191-209, 1986.

Le Fort, P., S. Guillot, and A. Pêcher, HP metamorphic belt along the Indus suture zone of NW Himalaya : new discoveries and significance, Compte Rendus Acad. Sci., 325, 773-778, 1997.

Le Goff, E., and M. Ballèvre, Geothermobarometry in the albite garnet orthogneisses : a case study from the Grand Paradiso nappe, Western Alps, Lithos, 25, 261-280, 1990.

Mahéo G., Bertrand H., Guillot S., Mascle G., Pêcher A., Picard C., de Sigoyer J. Les ophiolites Crétacé du sud Ladakh (NW-Himalaya, Inde) : Témoins d'un arc immature intraocéanique, Compte Rendu Acad. Sci., 330, p 289-295, 2000

Mascle, G., G. Hérail, T. Van Haver, and B. Delcaillau, Structure et évolution des bassins d'épisuture et de périsuture liés à la Chaîne Himalayenne., Bull. Centre Recherche Exploratoire Production Elf Aquitaine, 10, 181-203, 1986.

O'Brien, P.J., N. Zotov, R. Law, M.A. Khan, and M.Q. Jan, Coesite in Himalayan eclogite and implications for models of India-Asia collision, Geology (Boulder), 29, 435-438, 2001.

Patriat, P., and J. Achache, India-Eurasia collision chronology has implications for crustal shortening and driving mechanisms of plates, Nature, 311, 615-621, 1984.

Platt, J.P., Dynamic of orogenic wedges and the uplift of high-pressure metamorphic rocks., Bull. Geol. Soc. Am., 97, 1037-1053, 1986.

Platt, J.P., Exhumation of high-pressure metamorphic rocks : a review of concepts and processes, Terra Nova, 5, 119-133, 1993.

Pognante, U., and D.A. Spencer, First record of eclogites from the High Himalayan belt, Kaghan valley (northern Pakistan), Eur. J. Min., 3/3, 613-618, 1991.

Reuber, I., M. Colchen, and C. Mevel, The geodynamic evolution of the South-Tethyan margin in Zanskar, NW Himalaya, as revealed by the Spontang ophiolitic melange, Geodinamica Acta, 1, 283-296, 1987. 
Robertson, A.H.F., Formation of mélanges in the Indus suture zone, Ladakh Himalaya by successive subduction-related, collisional and post-collisional processes during Late MesozoicLate Tertiary time, in M.A. Khan, P.J. Treloar, M.P. Searle, M.Q. Jan, Tectonics of the Nanga Parbat syntaxis and the western Himalaya, Geol. Soc. Sp. Pub., 170, 333-374, 2000.

Rolland Y., Lardeaux J.M., Guillot S., Nicollet C., Extension syn-convergence, poinconnement vertical et unités métamorphiques contrastées en bordure Ouest du Grand Paradis (Alpes Franco-Italiennes). Geodinamica Acta. 13, 133-148, 2000.

Rolland, Y., C. Picard, A. Pecher, H. Lapierre, D. Bosch, and F. Keller, The Cretaceous Ladakh arc of NW Himalaya; slab melting and melt-mantle interaction during fast northward drift of Indian Plate, Chemical Geology, 182, 139-178, 2002.

Ruppel, C., L. Royden, and K. Hodges, Thermal modelling of extensional tectonics: application to pressure-temperature-time history of metamorphic rocks, Tectonics, 7, 945-957, 1988.

Sachan, H.K., B.K. Mukherjee, Y. Ogasawara, S. Mayurama, Pandey, A. A.K.M., N. Yoshioka, and H. Ishida, Discovery of coesite from Indian Himalaya: consequences on Himalayan tectonics, UHPM Workshop, Waseda University, 4A04, 124-128, 2001.

Schlup, M., A. Carter, and A. Steck, Exhumation history revealed by fission track cooling ages in the North Himalayan Crystalline Zone of eastern Ladalkh, NW Himalaya, J. Asian Earth Sci., 19, 57-56, 2001.

Seeber, and A. Pêcher, Strain Partitioning along the Himalayan arc and the Nanga Parbat antiform, Geology, 26, 791-794, 1998.

Spalla, I., J.M. Lardeaux, G.V. Dal Piaz, G. Gosso, and B. Messiga, Tectonic significance of alpine eclogites, J. Geodyn., 21/3, 257-285, 1996.

Spencer, D.A., and D. Gebauer, Shrimp evidence for a Permian protolith age and a $44 \mathrm{Ma}$ metamorphic age for the himalayan eclogites (Upper Kaghan, Pakistan): Implications for the subduction of Tethys and the subdivision terminology of the NW Himalaya., 11th HimalayaKarakorum-Tibet Workshop, 147, 1996. 
Steck, A., J.L. Epard, J.C. Vannay, J. Hunziker, M. Girard, A. Moraro, and M. Robyr, Geological transect across the Tso Morari and Spiti areas: The nappe structures of the Tethys Himalaya, Eclog. Geol. Helv., 91, 103-121, 1998.

Stutz, E., and A. Steck, La terminaison occidentale du Cristallin de Tso Morari (HautHimalaya ; Ladakh méridional, Inde) : Subdivision et tectonique de nappe, Eclog. Geol. Helv., 79, 253-269, 1986.

Thakur, V.C., Deformation and metamorphism of the Tso Morari crystalline complex, Wadia Instit. Himal. Geol., 1-8, 1983.

Thakur, V.C., and Bhat, Interpretation of tectonic environment of Nidar ophiolite: a geochemical approach, Wadia Instit. Himal. Geol., 33-40, 1983.

Thompson, A., K. Schulmann, and J. Jezek, Extrusion tectonics and elevation of lower crustal metamorphic rocks on convergent orogens, Geology, 25, 491-494, 1997a.

Thompson, A.B., K. Schulmann, and J. Jezek, Thermal evolution and exhumation in obliquely convergent (transpressive) orogens, Tectonophysics, 280, 171-184, 1997b.

Treloar, P.J., R.D. Broughton, M.P. Williams, M.P. Coward, and B.F. Windley, Deformation, metamorphism and imbrication of the Indian plate, south of the Main Mantle Thrust, north Pakistan., J. Metam. Geol., 7, 111-126, 1989.

Trivedi, J.R., K. Kewal, Sharma, and K. Gopalan, Widespread Caledonian magmatism in Himalaya and its tectonic significiance, Terra cognita, 6, 144, 1986.

Van Haver, T., Étude stratigraphique sédimentologique et structurale d'un bassin d'avant arc : Exemple du Bassin de l'Indus, Ladakh, Himalaya, Ph. D. thesis, Univ. Joseph Fourrier, Grenoble I, France, 1984.

Van Haver, T., M. Bonhomme, G. Mascle, and J. Aprahamian, Analyses K/Ar de phyllites fines des formations détritiques de l'Indus au Ladakh(Inde). Mise en evidence de l'âge éocène supérieur du métamorphisme.,Comptes Rendus Acad. Sci., 302 serieII Nº6, 325-330, 1986.

Virdi, N.S., V.C. Thakur, and R.J. Azmi, Discovery and significance of Permien microsfossils in the Tso Morari crystallines of Ladakh, India, Himalayan Geology, 8, 993-1000, 1978. 
Weinberg, R.F., and W.J. Dunlap, Growth and deformation of the Ladakh batholith, northwest Himalayas : implications for timing of contiental collision and origin of calc-alcaline batholiths, J. Geol., 108, 303-320, 2000.

Yamamoto, K., Origin of blueschists-facies clasts in the Mariana forearc, western pacific, Geochem. J., 29, 259-275, 1995.

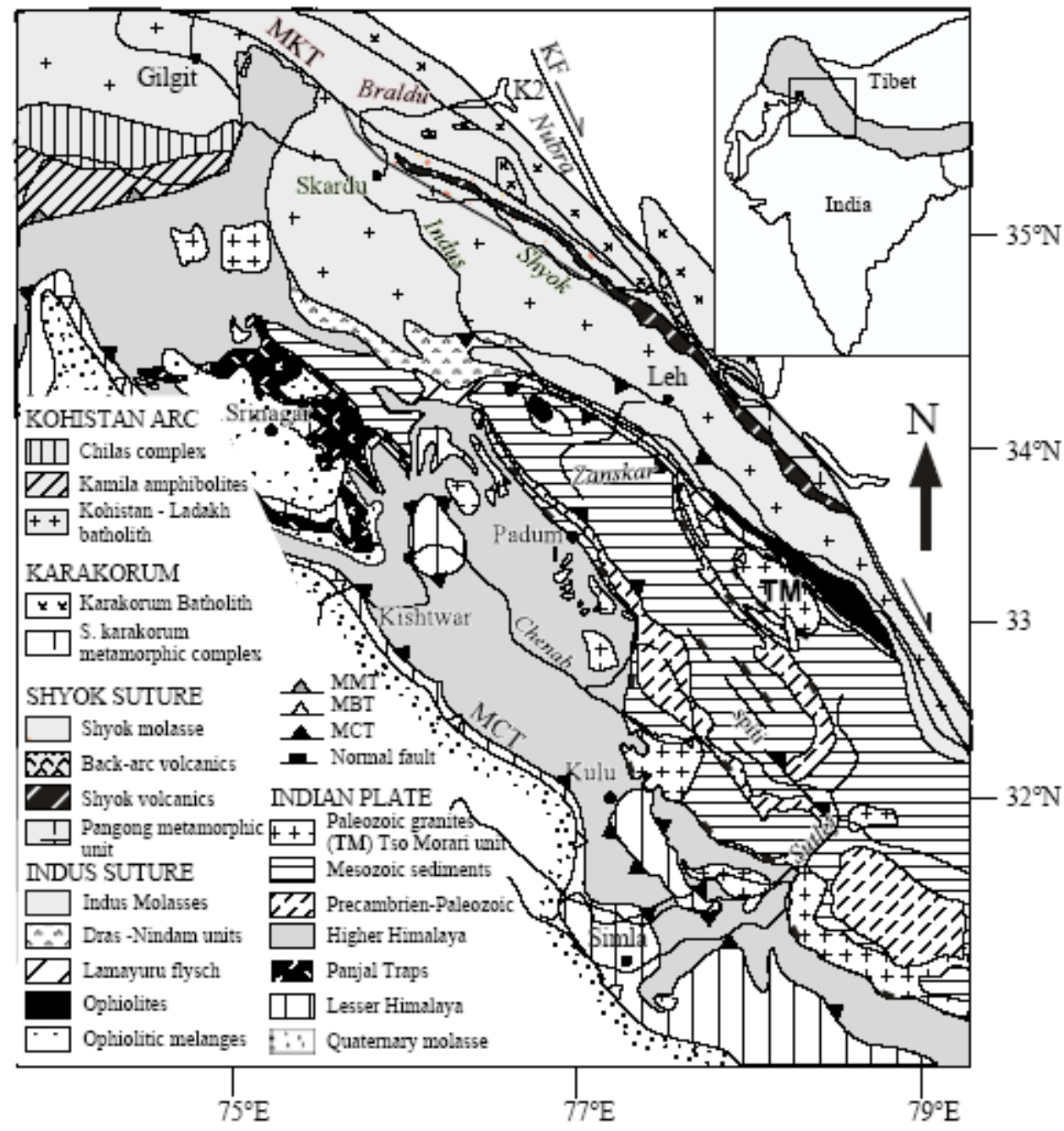

Figure 1. Geological map of the NW Himalaya, modified after Steck et al. [1998]. TM is the Tso Morari unit. Inset shows location of the study area. 


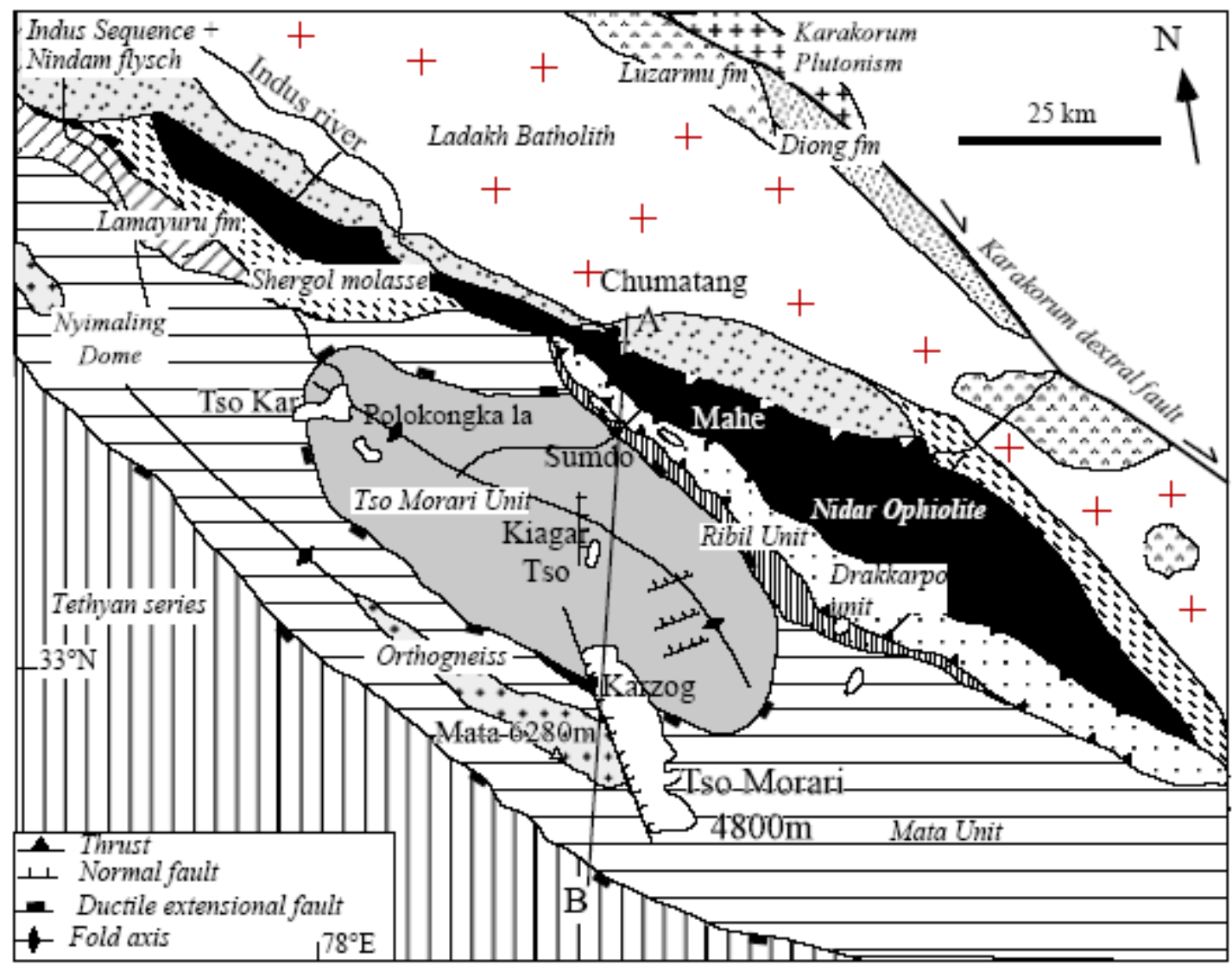

Figure 2. Geological map of the Tso Morari area based on satellite Spot images combined with our field observations and previous studies [Berthelsen, 1953; Thakur, 1983; Fuchs and Linner, 1996; Steck et al., 1998]. AB is trace of profil shown in Fig 3. 


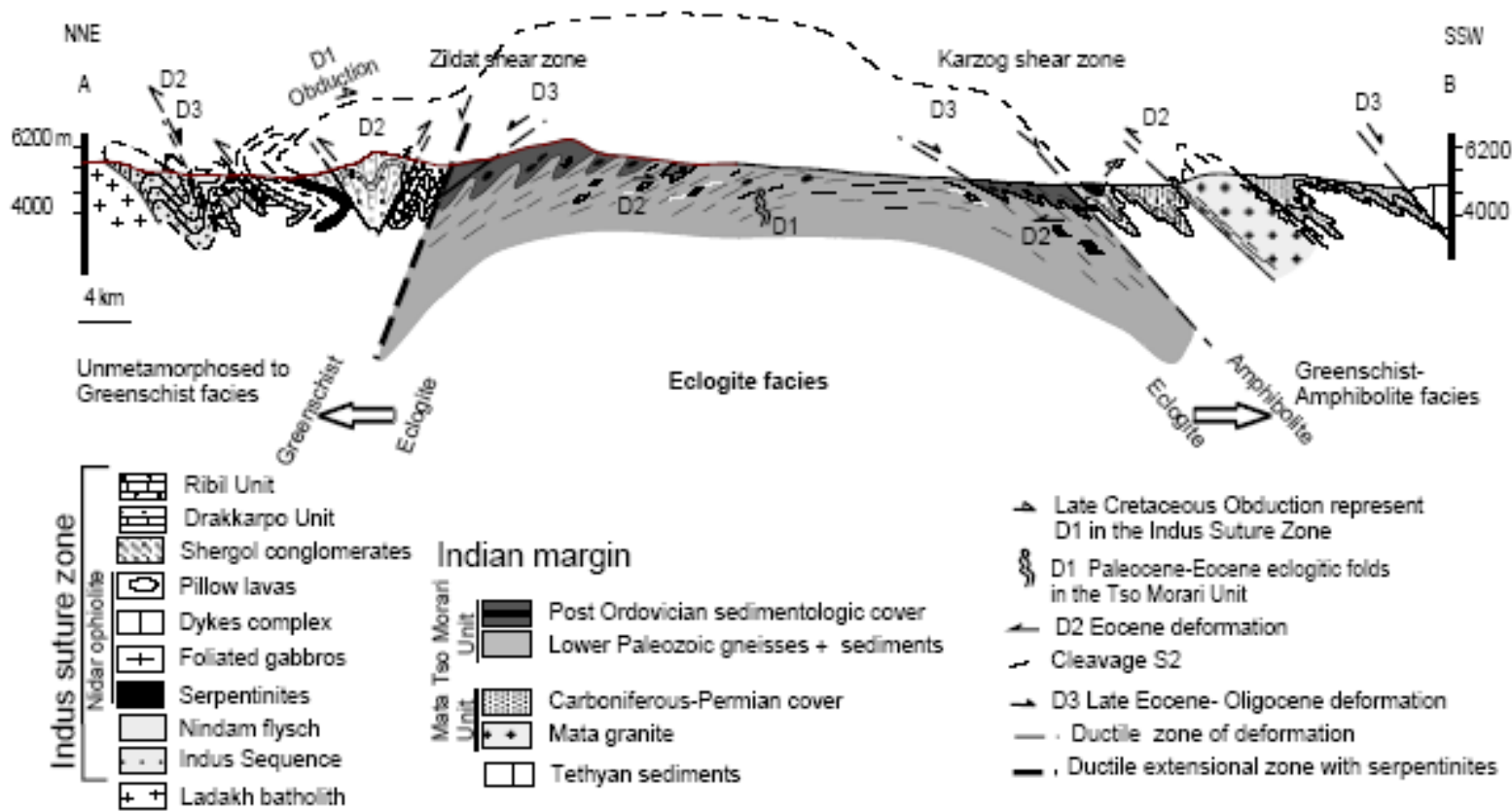

Figure 3. NS cross section from the Ladakh batholith $(A)$ to the Tethyan sediments $(B$; trace is given in Fig. 2) (sedimentary cover of the Indian margin). Deformation phase D1 corresponds to obduction of the Nidar ophiolite obduction, and to the eclogitization of Tso Morari Unit at Paleocene Eocene transition. D2 corresponds to the early part of the exhumation of the Tso Morari unit, D3 to the later part.

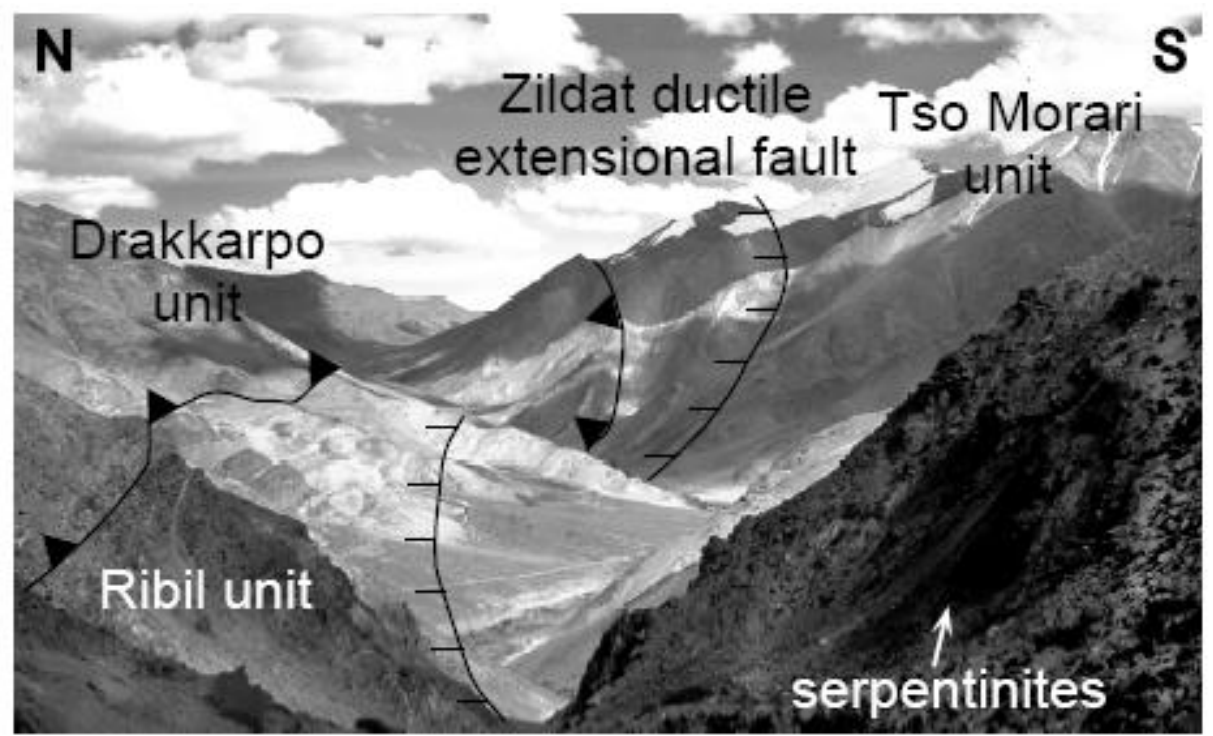

Figure 4. Photograph within the Zildat-Ribil valley of the Zildat normal shear zone. This shear zone separates the slightly metamorphosed Ribil unit from the Tso Morari eclogitic dome, serpentinite lenses underline this shear zone. This photograph also shows the thrusting contact between the Drakkarpo unit and the Ribil unit. 


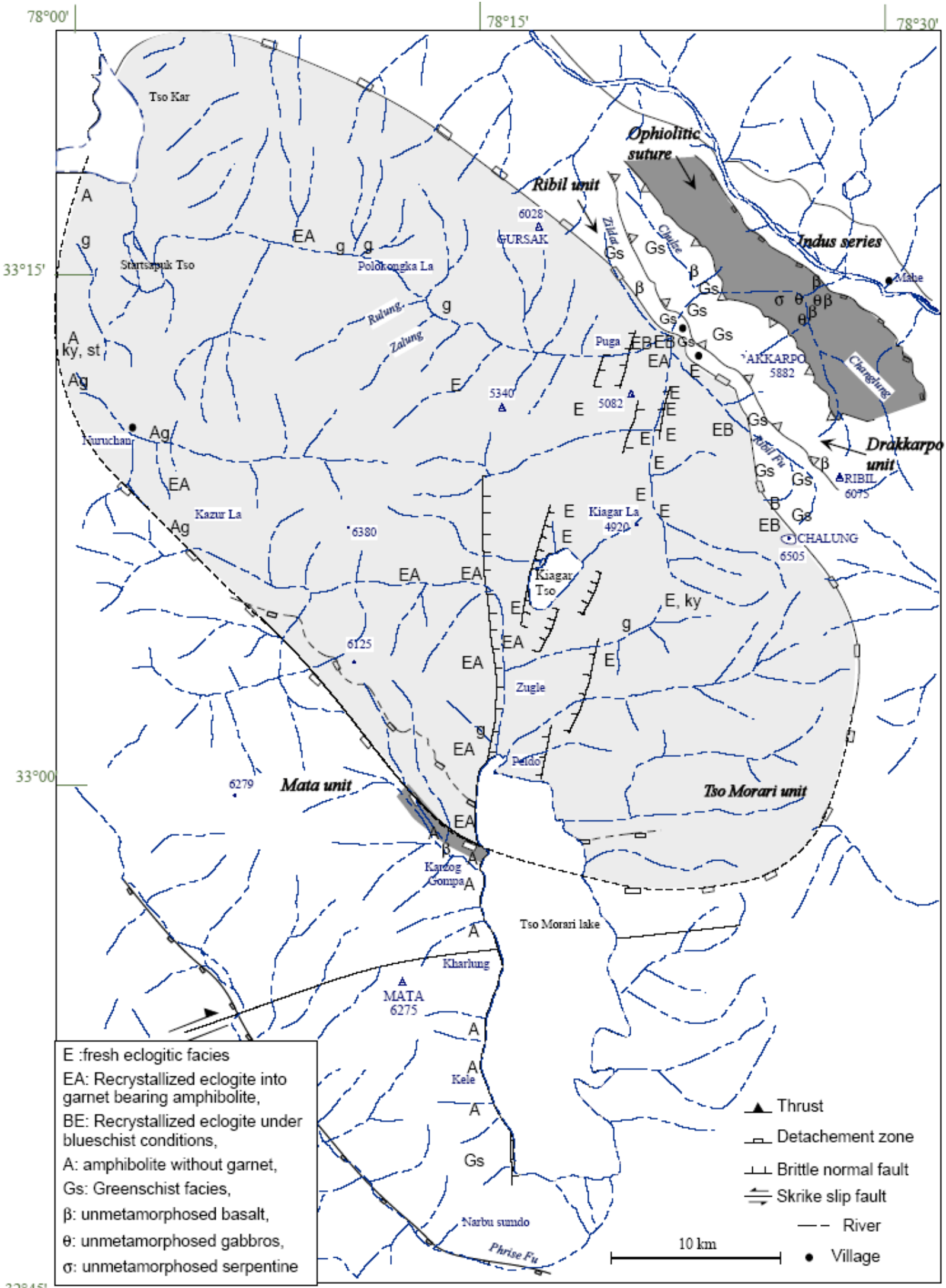

Figure 5. Map of the studied area showing the metamorphic facies or mineral occurrences in the metabasaltes and metapelites in the different units [de Sigoyer et al., 1997; Guillot et al., 1997]. The fresh eclogitic rocks are mainly preserved in the central part of the Tso Morari unit. In the northeast border of the Tso Morari unit, blueschists mineralogical assemblages overprint the eclogitic paragenesis, whereas eclogites are overprinted by garnet bearing amphibolite paragenesis in the western part of the Tso Morari unit. Note also the metamorphic contrast between the eclogitic Tso Morari unit and the surrounding units, metamorphosed under lower grade (epidote amphibolite to greenschist metamorphic facies). 
Figure 5. Map of the studied area showing the metamorphic facies or mineral occurrences in the metabasaltes and metapelites in the different units [de Sigoyer et al., 1997; Guillot et al., 1997]. The fresh eclogitic rocks are mainly preserved in the central part of the Tso Morari unit. In the northeast border of the Tso Morari unit, blueschists mineralogical assemblages overprint the eclogitic paragenesis, whereas eclogites are overprinted by garnet bearing amphibolite paragenesis in the western part of the Tso Morari unit. Note also the metamorphic contrast between the eclogitic Tso Morari unit and the surrounding units, metamorphosed under lower grade (epidote amphibolite to greenschist metamorphic facies).

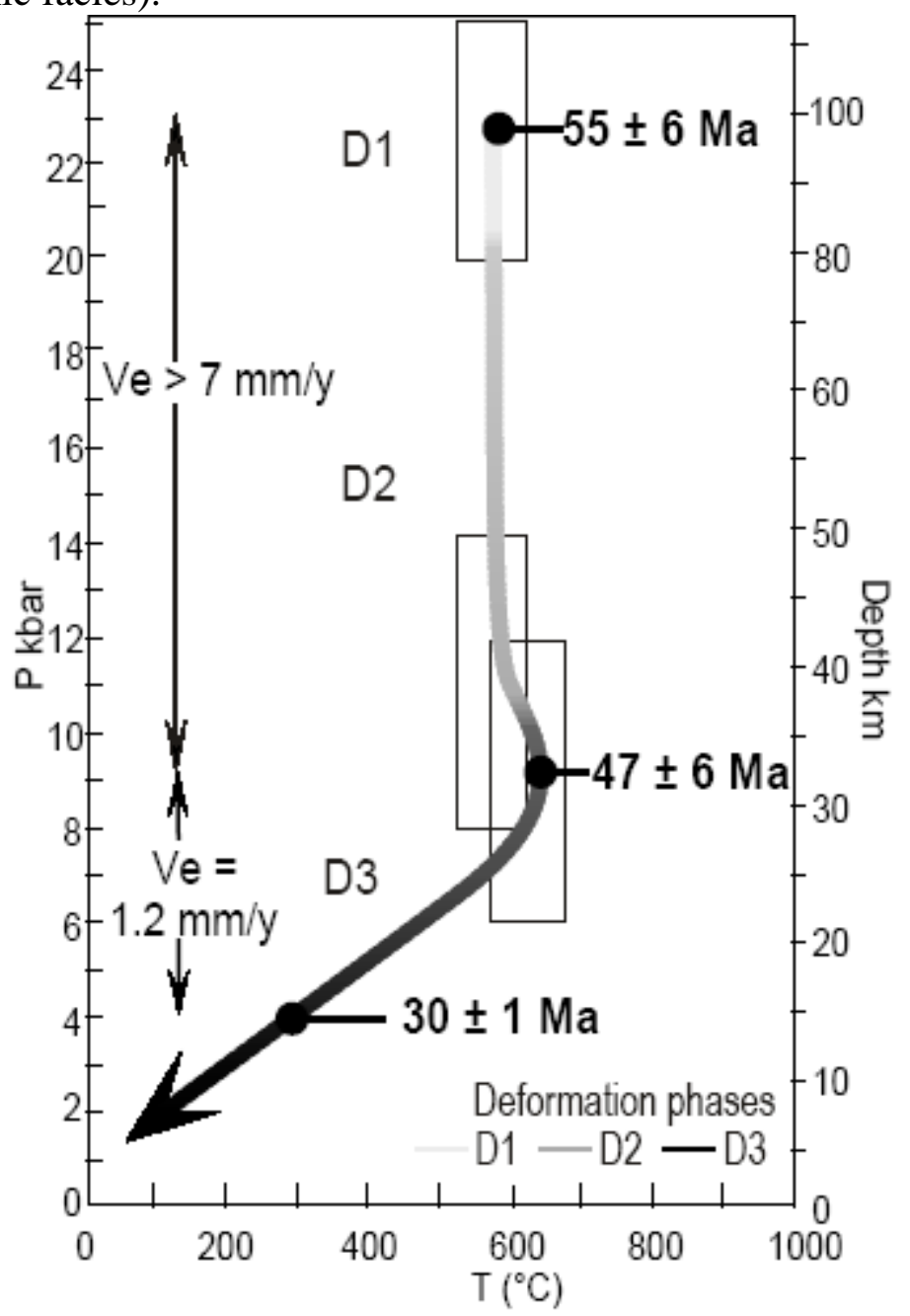

Figure 6. P-T-t path showing the tectometamorphic evolution of the Tso Morari unit deduced from samples coming from all over the unit [de Sigoyer et al., 2000; Sachan et al., 2001]. Boxes represent the different metamorphic stages. The ages of the Tso Morari evolution were obtained using different radio-chronological systems on specific paragenesis. The eclogitization is dated at 
about $55 \pm 7 \mathrm{Ma}$ by $\mathrm{Lu} / \mathrm{Hf}, \mathrm{Sm} / \mathrm{Nd}$ and $\mathrm{U} / \mathrm{Pb}$ geochronology on garnet-omphacite-whole rock, garnet-glaucophane-whole rock, and allanite respectively. Minerals related to amphibolite metamorphic recrystallization have been dated at about $47 \pm 6 \mathrm{Ma}$ ) by $\mathrm{Sm} / \mathrm{Nd}, \mathrm{Rb} / \mathrm{Sr}$ and ${ }^{40} \mathrm{Ar} /{ }^{39} \mathrm{Ar}$ geochronology on garnet-Ca-amphibole-whole rock (in the basic lens), phengite-apatite-whole rock, and phengite (on metapelites) respectively. The end of the Tso Morari exhumation is dated by ${ }^{40} \mathrm{Ar} /{ }^{39} \mathrm{Ar}$ age at $29 \pm 0.4 \mathrm{Ma}$ on biotites and muscovites which crystallized under greenschist conditions. $\mathrm{Ve}=$ estimated vertical exhumation rates deduced from ages and depth. 


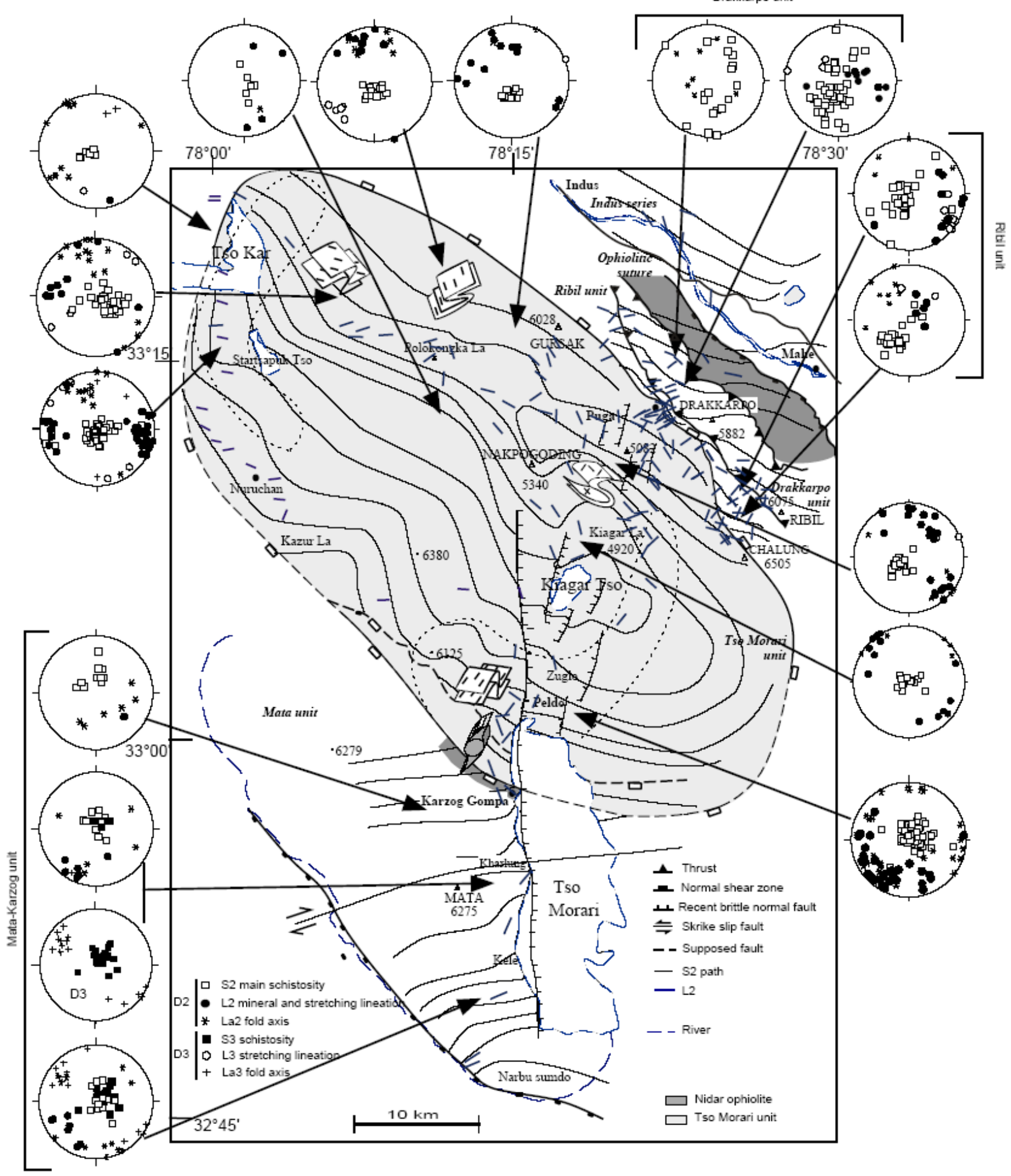

Figure 6. Structural map of the studied area showing the schistosity (S2) trajectories in the different units. Some stereoplots of the main schistosity (S2), of the mineral lineation $(\operatorname{lm} 2)$ and of stretching lineation $(1 \times 2)$ are shown in the Drakkarpo Unit, the Ribil Unit, the Tso Morari Unit, and the Mata Unit, (la2) represent the fold axis related to the D2 stage of deformation. Some D3 structures are also represented on this map on two stereoplots of the Mata unit and on the Tso Morari unit, S3 (schistosity), and fold axis (la3). 
Figure 7. Structural map and stereoplots of the studied area showing the structures related to the D2 deformation phase in the Drakkarpo, the Ribil, the Tso Morari, and the Mata units. Some D3 structures are also represented on this map in the Mata and Tso Morari units. 

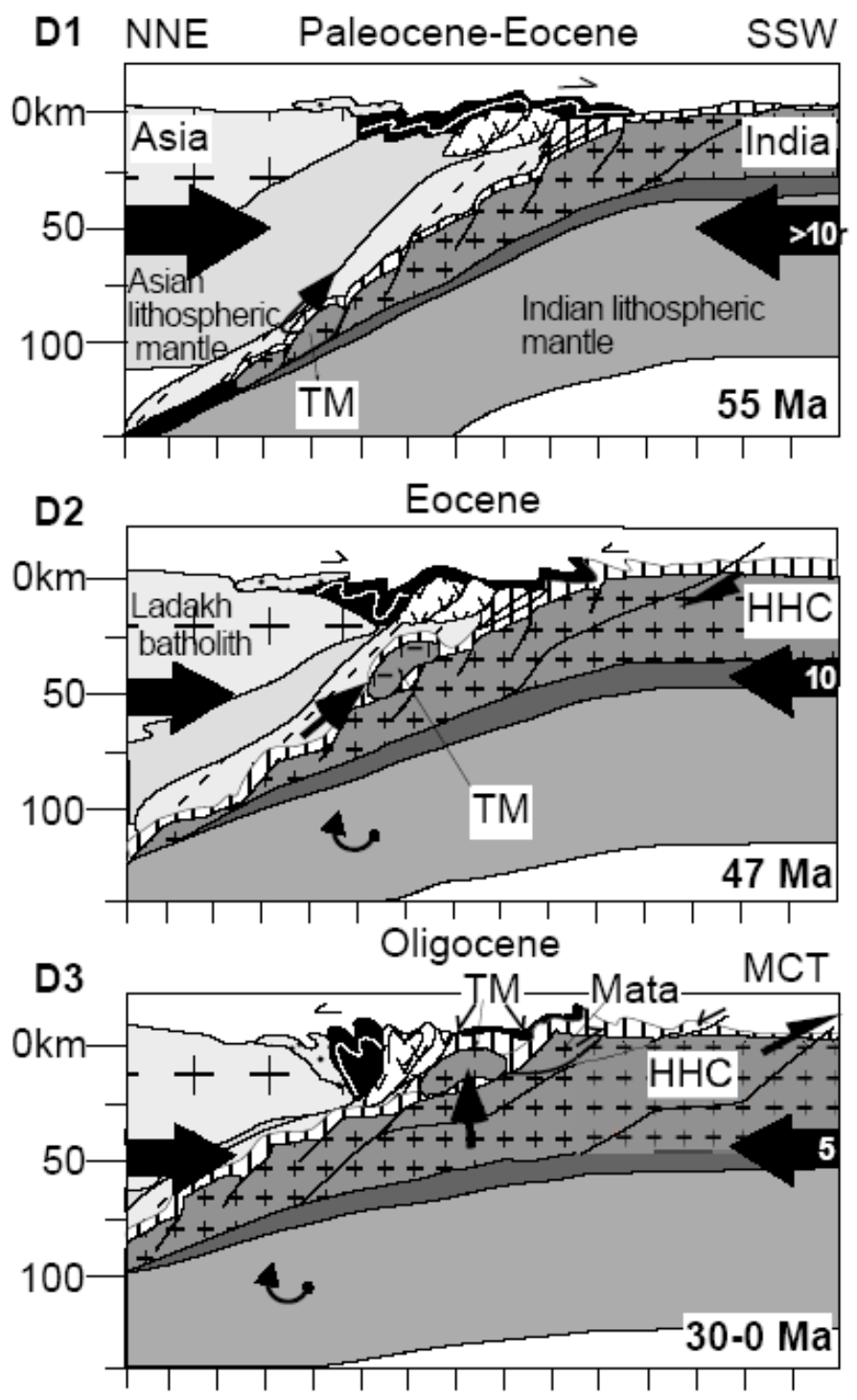

$\because$ Indus sediments

TM Tso Morari Unit

Nidar-Karzog ophiolite Mata Mata Unit

5 Serpentinized mantle wedge Tilting of the

¿v Drakkarpo-Ribil OIB

[L.] Indian upper crust

$\square$ Indian lower crust subduction plane

미 Tethyan sediments, indian margin

Figure 8. Simplified geodynamic evolution of the Tso Morari dome from the beginning of its exhumation. The geometrical observations done on the different units of the area suggest that the exhumation of the HP Tso Morari unit was mainly ruled by horizontal shortening between the Indian and Asian convergent landmasses. The Indian-Asian convergent rates are taken from Patriat and Achache, 1984. (HHC = Higher Himalayan Crystallines). 
Figure 8. Simplified geodynamic evolution of the Tso Morari dome exhumation. The geometrical observations done on the different units suggest that the exhumation of the UHP Tso Morari unit was mainly ruled by horizontal shortening between the Indian and Asian convergent landmasses. The Indian-Asian convergent rates are taken from Patriat and Achache, 1984. (HHC = Higher Himalayan Crystallines).

Plate 1. Photographs of D1-D2-D3 phases of deformation in the Tso Morari unit. (a) Field photograph of the F1 upright fold with axis $\left(\mathrm{N} 040^{\circ} / 10^{\circ}\right)$, close to the Pologonka La. F2 recumbent folds overprint $\mathrm{F} 1$ fold, $\mathrm{La} 2\left(\mathrm{~N} 175^{\circ} / 14^{\circ}\right)$. F1 and $\mathrm{F} 2$ affected the orthogneiss (o) the metabasaltes (mb) and the metapelites (mp). (b) Thin section photograph under crossed nikol of the eclogitic foliation in the core of a metabasic lens, underlined by the dynamic recrystallisation of omphacite (omph) and garnet (grt). (c) Thin section under crossed nikol of a Mg-rich metapelite showing the $\mathrm{S} 1$ foliation defined by kyanite and phengite (with a $\mathrm{Si}^{4+}$ content of 3.58 ). F2 folds folded $\mathrm{S} 1$ foliation during the retrogression under blueschist metamorphic conditions as shown by the crystallization of $\mathrm{Mg}$-chlorite and phengite with a $\mathrm{Si}^{4+}$ content of 3.45 in the hinge of the $\mathrm{F} 2$ fold. (d) Field photograph of deformed potassium feldspar porphyroclast in the northern limb of Tso Morari orthogneiss showing top to the SSW C2 movement (shear). (e) Metabasic lens in the southern limb of the Tso Morari Unit showing a (C2) top to the north shearing. (f) C3 normal shears in metabasic lenses in the northern limb of the dome showing top to the north movement. $(\mathrm{g})$ C3 normal shears in the orthogneiss showing top to the north extensional movement in the northern limb of the Tso Morari Unit. (h) C3 normal shears in the southern part of the Tso Morari orthogneiss. These C3 shear planes show top to the south normal movement. (i) Thin section view under crossed nikol of the $\mathrm{C} 3$ shears in a potassium rich metapelite sampled in the western part of the Tso Morari unit. Kyanite + biotite are developed in the C3 shear plane at the expense of staurolite + chlorite S2 foliation.

Table 1. This table summarized the structural features related to (D1-D2-D3) phases of deformation in the different units. 